\title{
Cacolides: Sesterterpene Butenolides from a Southern Australian Marine Sponge, Cacospongia sp.
}

\author{
Shamsunnahar Khushi, Laizuman Nahar, Angela A. Salim and Robert J. Capon * (d) \\ Institute for Molecular Bioscience, University of Queensland, St Lucia, QLD 4072, Australia; \\ s.khushi@imb.uq.edu.au (S.K.); 1.nahar@imb.uq.edu.au (L.N.); a.salim@uq.edu.au (A.A.S.) \\ * Correspondence: r.capon@uq.edu.au; Tel.: +61-7-3346-2979
}

Received: 26 October 2018; Accepted: 15 November 2018; Published: 20 November 2018

\begin{abstract}
Chemical analysis of a marine sponge, Cacospongia sp. (CMB-03404), obtained during deep sea commercial fishing activities off the southern coast of Australia, yielded an unprecedented family of sesterterpene $\alpha$-methyl- $\gamma$-hydroxybutenolides, cacolides A-L (1-12), together with biosynthetically related norsesterterpene carboxylic acids, cacolic acids A-C (13-15). Structures were assigned on the basis of detailed spectroscopic analysis with comparisons to known natural products and biosynthetic considerations. In addition to revealing new chemical diversity, this study provided a valuable platform for comparing and contrasting the capabilities of the traditional dereplication technologies of HPLC-DAD, HPLC-MS and NMR, with those of the emerging HPLC-MS/MS approach known as global natural products social molecular networking (GNPS), as applied to marine sponge sesterterpene tetronic acids.
\end{abstract}

Keywords: Cacospongia sp.; sesterterpene butenolides; dereplication; GNPS; sesterterpene tetronic acids

\section{Introduction}

Marine sponges (Phyla: Porifera) are a rich source of chemically diverse natural products. Indeed, some natural product structure classes unique to marine sponges have even been instrumental in informing systematic classifications. A case in point are the sesterterpene tetronic acids encountered in the Family: Irciniidae, Genera: Ircinia, Psammocinia and Sarcotragus [1]. Early accounts of Irciniidae sesterterpene tetronic acids include the 1972 report of ircinin-1 and ircinin-2 from Ircinia oros [2], and the 1973 report of variabilin from Ircinia variabilis [3], with absolute configurations for all three assigned in 1994 using metabolites from Australian Ircinia spp. [4]. The rapid pace of marine natural product discovery over the last four decades has included many accounts of Irciniidae sesterterpene tetronic acids, including from Australian Ircinia [5,6], Psammocinia [6-10] and Sarcotragus spp. [10]. As the prevalence of known sesterterpene tetronic acids increased, so did the need for rapid, reliable and cost effective dereplication. Dereplication strategies seek to analyse crude extracts/fractions, to achieve the early detection and de-prioritization of known chemistry, such as sponge sesterterpene tetronic acids, to ensure effective use of scientific resources. Modern dereplication strategies, which typically employ hyphenated chromatographic (i.e., HPLC, UPLC), spectroscopic (i.e., UV-vis, DAD, NMR) and/or spectrometric (i.e., MS) technologies, are generally effective at detecting sesterterpene tetronic acids in sponge extracts. As a result, many marine natural products researchers use these strategies to deprioritize such extracts at an early stage in the discovery process, in favour of extracts with a higher probability of returning new chemistry.

In this report, we describe an unprecedented family of sponge sesterterpenes, cacolides A-L (1-12) and related metabolites, cacolic acids A-C (13-15), isolated from a sponge extract initially dereplicated as containing sesterterpene tetronic acids. 


\section{Results and Discussion}

A portion of the aqueous EtOH extract from a specimen of sponge, Cacospongia sp. (CMB-03404), obtained in 2001 during deep-water commercial trawling operations in the Great Australian Bight, was concentrated in vacuo and the residue partitioned to yield $\mathrm{H}_{2} \mathrm{O}$ and $n-\mathrm{BuOH}$ solubles. The $n$ - $\mathrm{BuOH}$ solubles were then subjected to sequential solvent trituration to yield $n$-hexane, dichloromethane (DCM), $\mathrm{MeOH}$ and $\mathrm{H}_{2} \mathrm{O}$ soluble fractions. Preliminary high performance liquid chromatography diode array detection (HPLC-DAD) analysis revealed a complex array of metabolites concentrated in the DCM and $\mathrm{MeOH}$ fractions, although the DAD (UV-vis spectra) data proved uninformative for the purposes of dereplication. By contrast, the ${ }^{1} \mathrm{H} \mathrm{NMR}\left(\mathrm{CDCl}_{3}\right)$ data revealed resonances initially attributed to commonly encountered sponge sesterterpene tetronic acids, an assignment seemingly reinforced by high performance liquid chromatography mass spectrometry (HPLC-MS) analysis. With the ${ }^{1} \mathrm{H}$ NMR and HPLC-MS data suggesting an extract rich in known chemistry and antibacterial screening revealing an absence of growth inhibitory activity against a panel of Gram-positive and -negative pathogens, this extract was initially designated at a low priority for further chemical investigation. However, before leaving this extract to languish in our freezers, we noted a puzzling discrepancy. Sponge extracts rich in sesterterpene tetronic acids typically exhibit significant growth inhibitory activity against Gram-positive bacteria and on occasion against mammalian (i.e., cancer) cells. That the CMB-03404 extract did not exhibit such activity seemed incompatible with the preliminary determination that the extract was rich in sesterterpene tetronic acids. Intrigued by this anomaly, we re-prioritized the extract for detailed chemical analysis. Gratifyingly, solvent extraction followed by trituration and reversed-phase HPLC fractionation yielded a family of unprecedented sesterterpenes (1-15, Figure 1), with structure elucidation achieved by detailed spectroscopic analysis and biosynthetic considerations and reference to known sesterterpene tetronic acids (16-22, Figure 2), as outlined below.
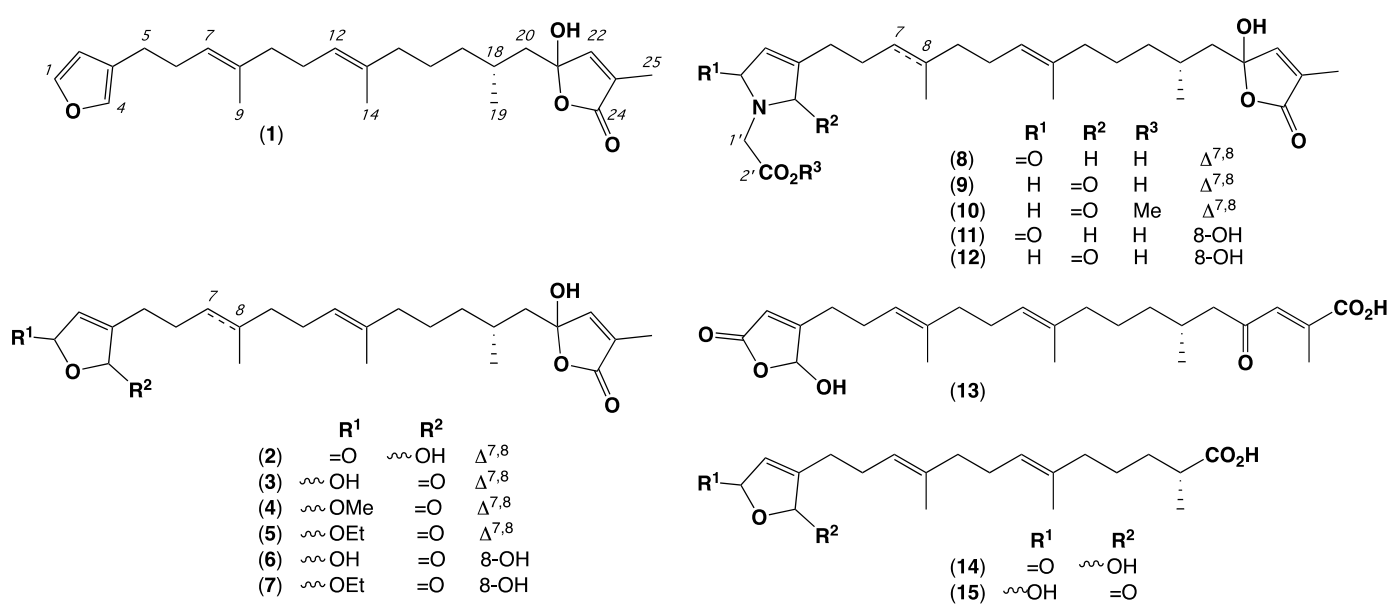

Figure 1. Cacospongia sp. (CMB-03404) metabolites 1-15. 

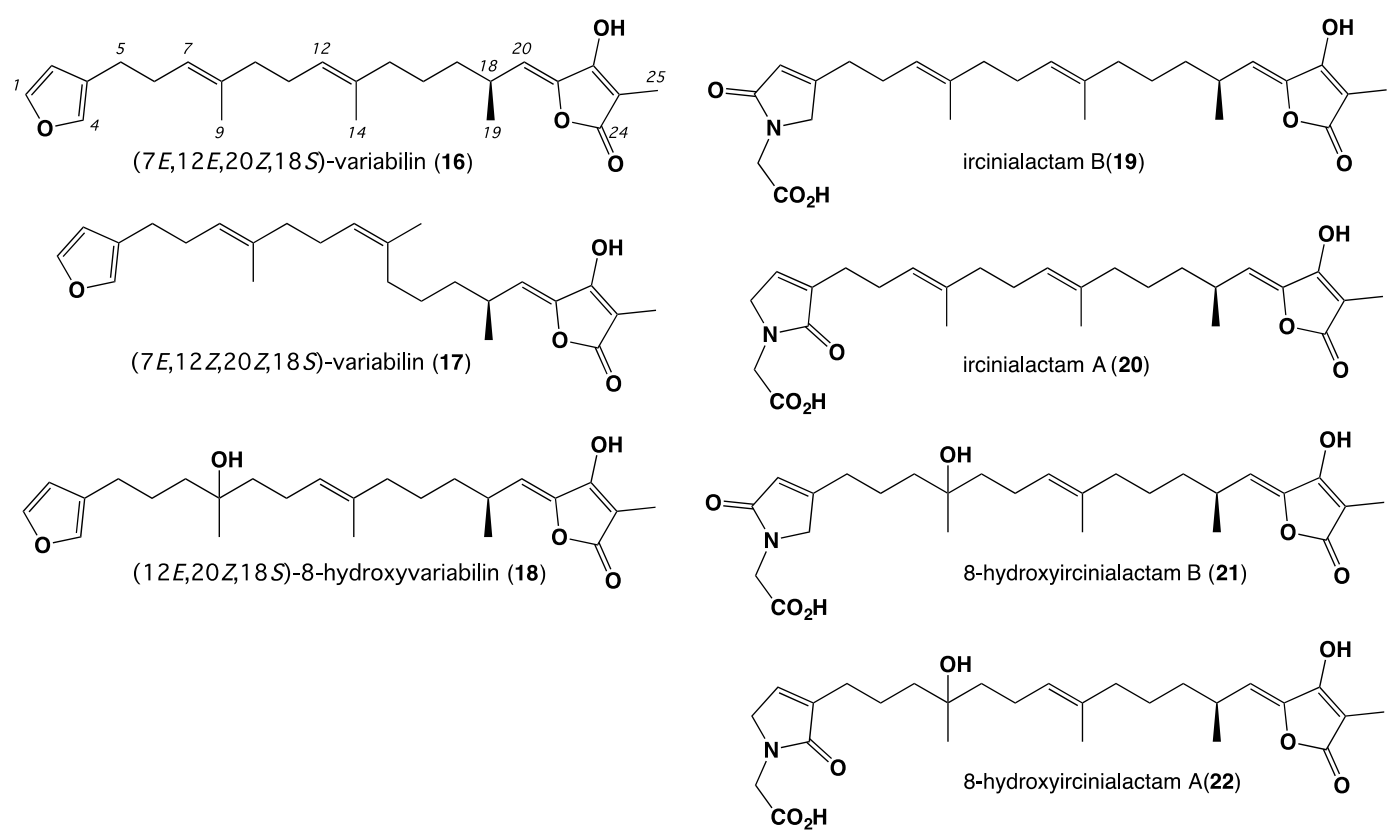

Figure 2. Selected known Irciniidae sesterterpene tetronic acids 16-22.

High resolution electrospray ionisation, positive mode mass spectrometry (HRESI(+)MS) analysis of 1 revealed a sodium adduct ion attributed to a molecular formula $\left(\mathrm{C}_{25} \mathrm{H}_{36} \mathrm{O}_{4}, \Delta \mathrm{mmu}-0.5\right)$ consistent with a dihydro analogue of the known sponge metabolite $(7 E, 12 E, 20 Z, 18 S)$-variabilin (16) (whose planar structure was first reported as variabilin) $[3,4,6,10]$. Consistent with this hypothesis, the NMR $\left(\mathrm{CDCl}_{3}\right)$ data for $\mathbf{1}$ (Tables 1 and 2 and Table S1) displayed resonances for a C-1 to C-19 structure fragment in common with 16. The $E \Delta^{7}$ and $E \Delta^{12}$ configurations were evident from shielded ${ }^{13} \mathrm{C}$ NMR chemical shifts for C-9 $\left(\delta_{C} 16.2\right)$ and C-14 $\left(\delta_{C} 16.0\right)$, compared to the known Psammocinia metabolite (7E,12Z,20Z,18S)-variabilin (17) $\left(E \Delta^{7} \delta_{C} 16.4, C-9 ; Z \Delta^{12} \delta_{C} 24.1, C-14\right)$ [10], as well as diagnostic rotating-frame nuclear Overhauser effect (ROESY) correlations between H-7 and $\mathrm{H}_{2}-10$ and between $\mathrm{H}-12$ and $\mathrm{H}_{2}-15$ (Figure 3). Principle differences in the NMR data for 1 compared to 16 were consistent with hydration of $Z \Delta^{20}$ in 16 to deliver a C-21 acetal $\left(\delta_{C} 106.2\right)$ in 1 and replacement of the C-21 to C-25 $\alpha$-methyl-tetronic acid moiety in 16 (i.e., C-22 $\delta_{C}$ 166.8) [6], with an $\alpha$-methyl- $\gamma$-hydroxy- $\gamma$-substituted butenolide in 1 (i.e., $\mathrm{H}-22 \delta_{\mathrm{H}} 6.82$; C-22 $\delta_{\mathrm{C}} 147.6$ ) (Figure 3 ). Based on the above and other 2D NMR correlations (Figure 3), the planar structure for cacolide A (1) was assigned as shown (Figure 1).

HRESI(+)MS analysis of 2 revealed a sodium adduct ion attributed to a molecular formula $\left(\mathrm{C}_{25} \mathrm{H}_{36} \mathrm{O}_{6}, \Delta \mathrm{mmu}-0.7\right)$ consistent with an oxidized $\left(+\mathrm{O}_{2}\right)$ analogue of $\mathbf{1}$. Comparison of the NMR $\left(\mathrm{CDCl}_{3}\right)$ data for 2 (Tables 1 and 2 and Table S2) with 1 revealed key differences associated with oxidation of the C-1 to C-4 furan moiety in 1 , to an $\beta$-substituted $\gamma$-hydroxybutenolide in $2\left(\mathrm{C}-1 \delta_{\mathrm{C}}\right.$ 170.0; $\left.\mathrm{H}-4 \delta_{\mathrm{H}} 6.01 ; \mathrm{C}-4 \delta_{\mathrm{C}} 99.5\right)$, with the butenolide regiochemistry confirmed by a heteronuclear multiple bond correlation (HMBC) from $\mathrm{H}_{2}-5$ to a C-4 acetal methine $\left(\delta_{C} 99.5\right)$ (Figure 3). Based on the above and other diagnostic 2D NMR correlations (Figure 3), the planar structure for cacolide B (2) was assigned as shown (Figure 1).

HRESI(+)MS analysis of 3 revealed a sodium adduct ion attributed to a molecular formula $\left(\mathrm{C}_{25} \mathrm{H}_{36} \mathrm{O}_{6}, \Delta \mathrm{mmu}+0.6\right)$ consistent with an isomer of 2 . Comparison of the NMR $\left(\mathrm{CDCl}_{3}\right)$ data for 3 (Table 1, Table 2 and Table S3) with 2 revealed a common C-5 to C-25 structure fragment, with the key differences being attributed to an alternate $\mathrm{C}-1$ to $\mathrm{C}-4 \alpha$-substituted $\gamma$-hydroxybutenolide regiochemistry $\left(\mathrm{H}-1 \delta_{\mathrm{H}} 6.09 ; \mathrm{C}-1 \delta_{\mathrm{C}} 97.2 ; \mathrm{C}-4 \delta_{\mathrm{C}} 172.5\right)$, the latter independently confirmed by an $\mathrm{HMBC}$ from $\mathrm{H}_{2}-5$ to a C-4 carbonyl ( $\left.\delta_{C} 172.5\right)$ (Figure 3). Based on the above and other diagnostic $2 \mathrm{D}$ NMR correlations (Figure 3), the planar structure for cacolide C (3) was assigned as shown (Figure 1). 


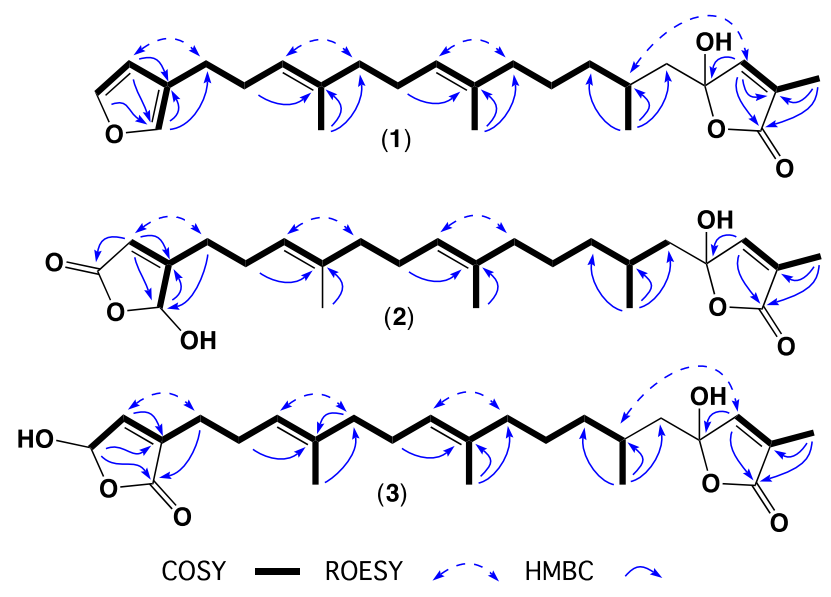

Figure 3. Selected $2 \mathrm{D} \mathrm{NMR}\left(\mathrm{CDCl}_{3}\right)$ correlations for cacolides $\mathrm{A}-\mathrm{C}(\mathbf{1}-\mathbf{3})$.

Table 1. ${ }^{13} \mathrm{C}(150 \mathrm{MHz})$ NMR Data for 1-7 in $\mathrm{CDCl}_{3}$.

\begin{tabular}{cccccccc}
\hline Position & $\mathbf{1}$ & $\mathbf{2}$ & $\mathbf{3}$ & $\mathbf{4}$ & $\mathbf{5}$ & $\mathbf{6}$ & $\mathbf{7}$ \\
\hline 1 & 142.7 & 170.0 & 97.2 & 102.6 & 101.6 & 96.9 & 101.8 \\
2 & 111.3 & 117.6 & 144.1 & 142.2 & 142.5 & 143.8 & 142.6 \\
3 & 125.2 & 171.1 & 137.8 & 138.6 & 138.3 & 137.8 & 138.5 \\
4 & 139.0 & 99.5 & 172.5 & 171.9 & 172.0 & 172.3 & 171.9 \\
5 & 25.2 & 28.0 & 25.4 & 25.5 & 25.5 & 25.5 & 25.9 \\
6 & 28.6 & 25.3 & 25.6 & 25.7 & 25.7 & 21.6 & 21.9 \\
7 & 123.9 & 122.6 & 122.9 & 122.6 & 122.7 & $41.5^{\mathrm{a}}$ & $41.6^{\mathrm{a}}$ \\
8 & 135.9 & 136.9 & 136.8 & 136.8 & 136.9 & 73.5 & 73.1 \\
9 & $16.2^{\mathrm{a}}$ & $16.1^{\mathrm{a}}$ & $16.1^{\mathrm{a}}$ & 16.3 & 16.0 & 26.4 & 26.9 \\
10 & 39.9 & 39.5 & 39.5 & 39.7 & 39.7 & $41.5^{\mathrm{a}}$ & $41.6^{\mathrm{a}}$ \\
11 & 26.7 & 25.9 & 26.1 & 26.5 & 26.5 & 22.9 & 22.8 \\
12 & 124.4 & 123.9 & 124.2 & 124.2 & 124.2 & 125.1 & 125.0 \\
13 & 135.1 & 135.4 & 135.3 & 135.2 & 135.3 & 135.2 & 135.9 \\
14 & $16.0^{\mathrm{a}}$ & $16.1^{\mathrm{a}}$ & $16.1^{\mathrm{a}}$ & 16.1 & 16.2 & 16.1 & 16.0 \\
15 & 39.9 & 39.8 & 39.8 & 39.9 & 39.8 & 39.3 & 39.5 \\
16 & 25.2 & 25.1 & 25.1 & 25.2 & 25.2 & 24.6 & 25.1 \\
17 & 37.6 & 37.5 & 37.5 & 37.5 & 37.3 & 36.6 & 37.5 \\
18 & 28.7 & 28.6 & 28.6 & 29.0 & 28.7 & 28.6 & 28.6 \\
19 & 21.1 & 21.1 & 21.2 & 21.3 & 21.2 & 21.1 & 21.0 \\
20 & 44.9 & 44.7 & 44.7 & 44.9 & 44.8 & $45.44^{\mathrm{b}}$ & 45.1 \\
21 & 106.2 & 107.0 & 107.0 & 105.8 & 106.1 & 107.5 & 106.0 \\
22 & 147.6 & 148.0 & 148.0 & 147.6 & 147.6 & 147.6 & 147.5 \\
23 & 132.1 & 131.9 & 131.8 & 135.2 & 132.0 & 131.7 & 132.3 \\
24 & 171.9 & 172.6 & 172.6 & 171.2 & 172.0 & 172.0 & 173.0 \\
25 & 10.7 & 10.6 & 10.6 & 10.8 & 10.6 & 10.7 & 10.6 \\
$1-\mathrm{OM}_{2}$ & & & & 57.3 & & & \\
$1-\mathrm{OC} \mathrm{CH}_{2} \mathrm{CH}_{3} \mathrm{CH}_{3}$ & & & & & 66.0 & & 66.2 \\
\hline
\end{tabular}

a Resonances with the same superscript within a column are interchangeable, ${ }^{\mathrm{b}}$ Detected from HMBC. 
Table 2. ${ }^{1} \mathrm{H}(600 \mathrm{MHz}) \mathrm{NMR}$ Data for $1-4$ in $\mathrm{CDCl}_{3}$.

\begin{tabular}{|c|c|c|c|c|}
\hline Position & $\stackrel{1}{\delta_{\mathrm{H}}, \mathrm{m}(\mathrm{J} \text { in } \mathrm{Hz})}$ & $\stackrel{2}{\delta_{\mathrm{H}}, \mathrm{m}(J \text { in } \mathrm{Hz})}$ & $\stackrel{3}{\delta_{\mathrm{H}}, \mathrm{m}(J \text { in } \mathrm{Hz})}$ & $\stackrel{4}{\delta_{\mathrm{H}}, \mathrm{m}(J \text { in } \mathrm{Hz})}$ \\
\hline 1 & 7.33 , br s & & 6.09, br s & 5.74, br s \\
\hline 2 & 6.28, br s & 5.83, br s & $6.84^{\mathrm{a}}, \mathrm{br} \mathrm{s}$ & 6.78, br s \\
\hline 4 & 7.21, br s & 6.01, br s & & \\
\hline 5 & $2.45, \mathrm{t}(7.7)$ & a $2.52, \mathrm{mb} 2.39, \mathrm{~m}$ & $2.32, \mathrm{t}(7.3)$ & $2.34, \mathrm{t}(7.3)$ \\
\hline 6 & 2.24, dt 7.3, 7.7) & $2.30, \mathrm{dt}(7.2,7.2)$ & $2.26, \mathrm{dt}(7.2,7.3)$ & $2.26, \mathrm{dt}(7.3,7.2)$ \\
\hline 7 & $5.16($ br t, 7.3$)$ & 5.09, br t $(7.2)$ & 5.09, br t, $(7.2)$ & 5.10, br t $(7.2)$ \\
\hline 9 & $1.59, \mathrm{~s}$ & $1.61(\mathrm{~s})$ & $1.59, \mathrm{~s}$ & $1.61, \mathrm{~s}$ \\
\hline 10 & $2.01, \mathrm{t}(7.4)$ & $2.02, \mathrm{t}(7.0)$ & $2.01, \mathrm{t}(7.0)$ & $2.01, \mathrm{t}(7.0)$ \\
\hline 11 & 2.07, dt $(7.4,7.4)$ & $2.09, \mathrm{dt}(7.0,7.0)$ & $2.08, \mathrm{dt}(7.0,7.3)$ & $2.08, \mathrm{dt}(7.0,7.3)$ \\
\hline 12 & 5.04, br t $(7.4)$ & 5.02, br t $(7.0)$ & 5.04, br t $(7.3)$ & 5.07 , br t $(7.3)$ \\
\hline 14 & $1.57, \mathrm{~s}$ & $1.56(\mathrm{~s})$ & $1.56, \mathrm{~s}$ & $1.57, \mathrm{~s}$ \\
\hline 15 & $1.93^{\mathrm{a}}$ & $1.91, \mathrm{~m}$ & $1.92, \mathrm{~m}$ & $1.94^{\mathrm{a}}, \mathrm{m}$ \\
\hline 16 & $1.36, \mathrm{~m}$ & $1.34, \mathrm{~m}$ & $1.35, \mathrm{~m}$ & $1.35, \mathrm{~m}$ \\
\hline \multirow{2}{*}{17} & a $1.30, \mathrm{~m}$ & a $1.29, \mathrm{~m}$ & a $1.30, \mathrm{~m}$ & a $1.30, \mathrm{~m}$ \\
\hline & b $1.16, \mathrm{~m}$ & b $1.14, \mathrm{~m}$ & b $1.14, \mathrm{~m}$ & b $1.17, \mathrm{~m}$ \\
\hline 18 & $1.64, \mathrm{~m}$ & $1.64, \mathrm{~m}$ & $1.63, \mathrm{~m}$ & $1.65, \mathrm{~m}$ \\
\hline 19 & 0.96, br d (6.7) & 0.94, br d (6.5) & 0.94, br d (6.3) & $0.96, \mathrm{~s}$ \\
\hline \multirow{2}{*}{20} & a $1.94^{\mathrm{a}}$ & a $1.95, \mathrm{~m}$ & a $1.93, \mathrm{~m}$ & a $1.94^{\mathrm{a}}, \mathrm{m}$ \\
\hline & b $1.74, \mathrm{~m}$ & $\mathrm{~b} 1.71, \mathrm{~m}$ & $\mathrm{~b} 1.71, \mathrm{~m}$ & $\mathrm{~b} 1.73, \mathrm{~m}$ \\
\hline 22 & $6.82, \mathrm{br} \mathrm{s}$ & 6.85 (br s) & $6.84^{\mathrm{a}}, \mathrm{br} \mathrm{s}$ & 6.84, br s \\
\hline 25 & $1.93^{\mathrm{a}}, \mathrm{s}$ & $1.90(\mathrm{~s})$ & $1.90, \mathrm{~s}$ & $1.94^{\mathrm{a}}, \mathrm{s}$ \\
\hline 1-OMe & & & & $3.56, \mathrm{~s}$ \\
\hline
\end{tabular}

HRESI(+)MS analysis of 4 and 5 revealed sodium adduct ions attributed to molecular formulae $\left(\mathrm{C}_{26} \mathrm{H}_{38} \mathrm{O}_{6}, \Delta \mathrm{mmu}+0.2\right.$ and $\left.\mathrm{C}_{27} \mathrm{H}_{40} \mathrm{O}_{6}, \Delta \mathrm{mmu}-0.8\right)$ consistent with methyl and ethyl homologues of 3, respectively. Comparison of the NMR $\left(\mathrm{CDCl}_{3}\right)$ data for 4 and 5 (Tables 1-3, Tables S4 and S5), with 3, revealed a common carbon skeleton, including a C-1 to C-4 $\alpha$-substituted $\gamma$-hydroxybutenolide terminus, with the key differences being the appearance of $1-\mathrm{OCH}_{3}\left(\delta_{\mathrm{H}} 3.56 ; \delta_{\mathrm{C}} 57.3, \mathrm{OCH}_{3}\right)$ and $1-\mathrm{OCH}_{2} \mathrm{CH}_{3}\left(\delta_{\mathrm{H}} 3.73 / 3.91\right.$ and $\delta_{\mathrm{C}} 66.0, \mathrm{OCH}_{2} \mathrm{CH}_{3} ; \delta_{\mathrm{H}} 1.27$ and $\left.\delta_{\mathrm{C}} 15.2, \mathrm{OCH}_{2} \underline{\mathrm{CH}}_{3}\right)$ moieties. The regiochemistry of these alkylations was independently confirmed from HMBC correlations from $\mathrm{H}-1$ to $\mathrm{OCH}_{3}$ in 4 and $\mathrm{H}-1$ to $\mathrm{OCH}_{2} \mathrm{CH}_{3}$ in 5 (Figure 4). Based on the above, the planar structures for cacolides D (4) and E (5) were assigned as shown (Figure 1).

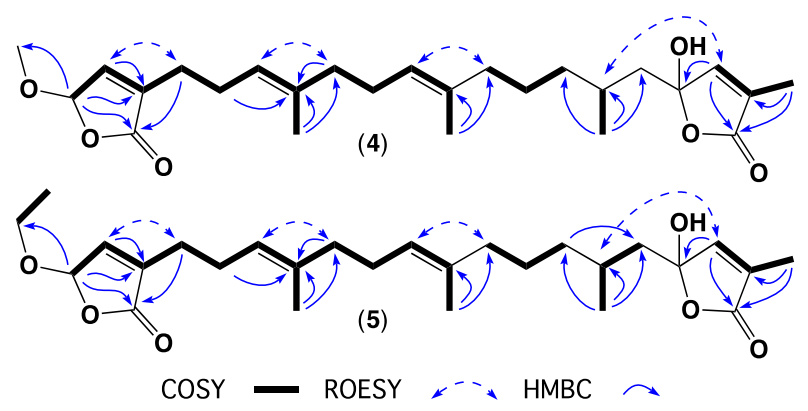

Figure 4. Selected 2D NMR $\left(\mathrm{CDCl}_{3}\right)$ correlations for cacolides D-E (4-5). 
Table 3. ${ }^{1} \mathrm{H}(600 \mathrm{MHz}) \mathrm{NMR}$ Data for 5-8 in $\mathrm{CDCl}_{3}$.

\begin{tabular}{|c|c|c|c|}
\hline Position & $\begin{array}{c}5 \\
\delta_{\mathrm{H}}, \mathrm{m}(J \text { in } \mathrm{Hz})\end{array}$ & $\begin{array}{c}6 \\
\delta_{H}, m(J \text { in } H z)\end{array}$ & $\begin{array}{c}7 \\
\delta_{\mathrm{H}}, \mathrm{m}(J \text { in } \mathrm{Hz})\end{array}$ \\
\hline 1 & 5.80, br s & 6.05 , br s & 5.82, br s \\
\hline 2 & $6.78, \mathrm{~d}(1.4)$ & 6.89 , br s & 6.81 , br s \\
\hline 5 & $2.33, \mathrm{t}(7.3)$ & $2.32, \mathrm{~m}$ & $2.30,(7.3)$ \\
\hline 6 & $2.26, \mathrm{dt}(7.2,7.3)$ & $1.64^{\mathrm{a}}$ & $1.64^{\mathrm{a}}$ \\
\hline 7 & 5.10, br t $(7.2)$ & $\begin{array}{l}\text { a } 1.55^{b} \\
\text { b } 1.50^{c}\end{array}$ & $\begin{array}{l}\text { a } 1.64^{a} \\
\text { b } 1.51^{b}\end{array}$ \\
\hline 9 & $1.59, \mathrm{~s}$ & $1.19, \mathrm{~s}$ & $1.18, \mathrm{~s}$ \\
\hline 10 & $1.99, \mathrm{t}(7.0)$ & $\begin{array}{l}\text { a } 1.55^{b} \\
\text { b } 1.50^{c}\end{array}$ & $\begin{array}{l}\text { a } 1.64^{\mathrm{a}} \\
\mathrm{b} 1.51^{\mathrm{b}}\end{array}$ \\
\hline 11 & $2.06, \mathrm{dt}(7.3,7.0)$ & $2.07, \mathrm{~m}$ & $2.05, \mathrm{~m}$ \\
\hline 12 & 5.06, brt $(7.3)$ & $5.27(\mathrm{~m})$ & $5.15, \mathrm{~m}$ \\
\hline 14 & $1.57, \mathrm{~s}$ & $1.64^{\mathrm{a}}, \mathrm{br} \mathrm{s}$ & 1.60 , br s \\
\hline 15 & $1.93^{\mathrm{a}}, \mathrm{m}$ & $1.97, \mathrm{~m}$ & $1.96, \mathrm{~m}$ \\
\hline 16 & $1.36, \mathrm{~m}$ & $1.41, \mathrm{~m}$ & $1.36, \mathrm{~m}$ \\
\hline 17 & $\begin{array}{c}\text { a } 1.27^{\mathrm{b}}, \mathrm{m} \\
\mathrm{b} 1.15, \mathrm{~m}\end{array}$ & $\begin{array}{l}\text { a } 1.31, \mathrm{~m} \\
\mathrm{~b} 1.11, \mathrm{~m}\end{array}$ & $\begin{array}{l}\text { a } 1.33, \mathrm{~m} \\
\mathrm{~b} 1.13, \mathrm{~m}\end{array}$ \\
\hline 18 & $1.67, \mathrm{~m}$ & $1.70, \mathrm{~m}$ & $1.66, \mathrm{~m}$ \\
\hline 19 & $0.96, \mathrm{~s}$ & 0.94, br d $(7.0)$ & 0.96, br d (6.8) \\
\hline 20 & $\begin{array}{l}\text { a } 1.93^{\mathrm{a}} \\
\mathrm{b} 1.73, \mathrm{~m}\end{array}$ & \# & $\begin{array}{c}\text { a } 1.93^{\mathrm{c}}, \mathrm{m} \\
\text { b } 1.72, \mathrm{~m}\end{array}$ \\
\hline 22 & 6.83 , br s & 6.85 , br s & 6.83 , br s \\
\hline 25 & $1.93^{\mathrm{a}}, \mathrm{s}$ & $1.91, \mathrm{~s}$ & $1.93^{c}, \mathrm{~s}$ \\
\hline $1-\mathrm{OCH}_{2} \mathrm{CH}_{3}$ & $\begin{array}{l}\text { a } 3.91, \mathrm{~m} \\
\text { b } 3.73, \mathrm{~m}\end{array}$ & & $\begin{array}{l}\text { a } 3.93, \mathrm{~m} \\
\text { b } 3.74, \mathrm{~m}\end{array}$ \\
\hline $1-\mathrm{OCH}_{2} \mathrm{CH}_{3}$ & $1.27^{\mathrm{b}}, \mathrm{t}(7.0)$ & & $1.27, \mathrm{t}(7)$ \\
\hline
\end{tabular}

HRESI(+)MS analysis of 6 and 7 revealed sodium adduct ions attributed to molecular formulae $\left(\mathrm{C}_{25} \mathrm{H}_{38} \mathrm{O}_{7}, \Delta \mathrm{mmu}-1.1\right.$ and $\left.\mathrm{C}_{27} \mathrm{H}_{42} \mathrm{O}_{7}, \Delta \mathrm{mmu}+0.5\right)$ consistent with hydrated $\left(+\mathrm{H}_{2} \mathrm{O}\right)$ homologues of 3 and 5, respectively. Comparison of the NMR $\left(\mathrm{CDCl}_{3}\right)$ data for 6 and 7 (Table 1, Table 3, Tables S6 and S7), with 3 and 5 , revealed the key differences as hydration of $\Delta^{7}$ in $3\left(C-7 \delta_{C} 122.9 ; C-8 \delta_{C}\right.$ $136.8)$ and $5\left(C-7 \delta_{C} 122.7 ; C-8 \delta_{C} 136.9\right)$, to yield a common $C-83^{\circ}-\mathrm{OH}$ in $6\left(\mathrm{C}-7 \delta_{C} 41.5 ; \mathrm{C}-8 \delta_{C} 73.5\right)$ and 7 (C-7 $\delta_{C} 41.6$; C-8 $\left.\delta_{C} 73.1\right)$. The NMR data for 6 and 7 compared favourably with the known Sarcotragus metabolite (12E,20Z,18S)-8-hydroxyvariabilin (18) [6,11], with the C-1 to C-4 $\alpha$-substituted $\gamma$-hydroxybutenolide regiochemistry confirmed by $\mathrm{HMBC}$ correlations from $\mathrm{H}_{2}-5$ to C-4 carbonyls $\left(6 \delta_{C} 172.3 ; 7 \delta_{C} 171.9\right)$ (Figure 5). Based on the above, the planar structures for cacolides $F(6)$ and $G$ (7) were assigned as shown (Figure 1). Cacolides E (5) and G (7) are likely ethanolysis artefacts of 3 and 6, respectively, induced during prolonged storage in $\mathrm{EtOH}$.

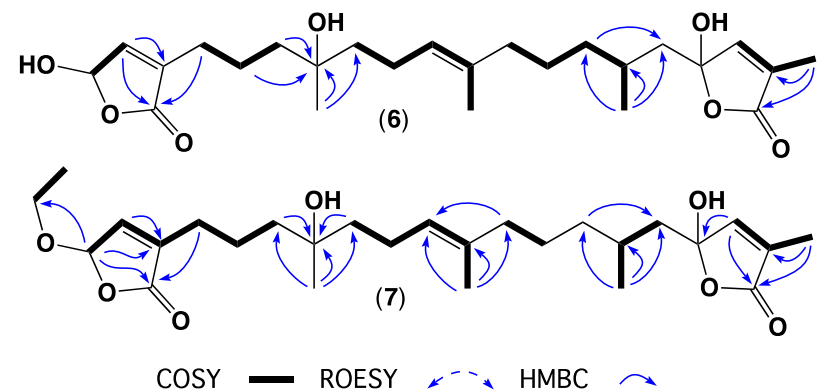

Figure 5. Selected $2 \mathrm{D}$ NMR $\left(\mathrm{CDCl}_{3}\right)$ correlations for cacolides $\mathrm{F}-\mathrm{G}(\mathbf{6}-\mathbf{7})$.

HRESI(+)MS analysis of 8 and 9 revealed sodium adduct ions attributed to isomeric molecular formulae $\left(\mathrm{C}_{27} \mathrm{H}_{39} \mathrm{NO}_{6}, \Delta \mathrm{mmu}+0.0\right.$ and -1.2$)$ consistent with dihydro analogues of the known 
Psammocinia metabolite ircinialactam B (19) [10], and Ircinia/Psammocinia metabolite ircinialactam A (20) $[6,10]$. Comparison of the NMR $\left(\mathrm{CDCl}_{3}\right)$ data for 8 and $\mathbf{9}$ (Table 4, Table 5, Tables S8 and S9) with co-metabolites 1-5 revealed a common C-5 to C-25 structure fragment. However, whereas 8 possessed a C-1 to C-4 $\beta$-substituted glycinyl lactam regiochemistry in common with 19, the co-metabolite 9 possessed an C-1 to C-4 $\alpha$-substituted glycinyl lactam regiochemistry in common with 20 . The lactam regiochemistry in 8 was further confirmed by an $\mathrm{HMBC}$ from $\mathrm{H}_{2}-5$ to a C-4 methylene $\left(\delta_{\mathrm{C}} 55.7\right)$, while that in 9 was confirmed by an $\mathrm{HMBC}$ from $\mathrm{H}_{2}-5$ to a $\mathrm{C}-4$ carbonyl $\left(\delta_{\mathrm{C}} 173.3\right)$ (Figure 6). Based on the above, the planar structures for cacolides $\mathrm{H}(\mathbf{8})$ and I (9) were assigned as shown (Figure 1).

HRESI(+)MS analysis of $\mathbf{1 0}$ revealed a sodium adduct ion attributed to a molecular formulae $\left(\mathrm{C}_{28} \mathrm{H}_{43} \mathrm{NO}_{6}, \Delta \mathrm{mmu}-0.1\right)$ consistent with a methylated analogue of 8 or 9. Comparison of the 1D and 2D NMR $\left(\mathrm{CDCl}_{3}\right)$ data for 10 (Table 4, Table 5 and Table S10) with 9 supported this hypothesis, including lactam regiochemistry and double bond conformations, with the new $\mathrm{OCH}_{3}\left(\delta_{\mathrm{H}} 3.74 ; \delta_{\mathrm{C}}\right.$ 52.4) positioned on the basis of an HMBC to the adjacent $\mathrm{C}-2^{\prime}$ carbonyl (Figure 6). Based on the above, the structure for cacolide J (10) was assigned as shown (Figure 1).

HRESI(+)MS analysis of $\mathbf{1 1}$ and $\mathbf{1 2}$ revealed sodium adduct ions attributed to isomeric molecular formulae $\left(\mathrm{C}_{27} \mathrm{H}_{41} \mathrm{NO}_{7}, \Delta \mathrm{mmu}+1.3\right.$ and -1.4) consistent with hydrated analogues of the co-metabolites 8 and 9. Comparison of the NMR $\left(\mathrm{CDCl}_{3}\right)$ data for $\mathbf{1 1}$ and $\mathbf{1 2}$ (Table 4, Table 5, Tables S11 and S12), with co-metabolites 8 and 9, revealed a common C-11 to C-25 structure fragment, with 11 sharing a $C-1$ to $C-5 \beta$-substituted glycinyl lactam moiety in common with $\mathbf{8}$ and $\mathbf{1 2}$ sharing a C-1 to C-5 $\alpha$-substituted glycinyl lactam in common with $\mathbf{9}$. Both 8 and 9 also shared a C-8 $3^{\circ}-\mathrm{OH}$ moiety in common with co-metabolites $\mathbf{6}$ and $\mathbf{7}$ and the known Ircinia metabolites, 8-hydroxyircinialactams B (21) [6] and A (22) [6]. Based on the above, plus diagnostic 2D NMR correlations (Figure 6), the planar structures for cacolides K (11) and L (12) were assigned as shown (Figure 1).
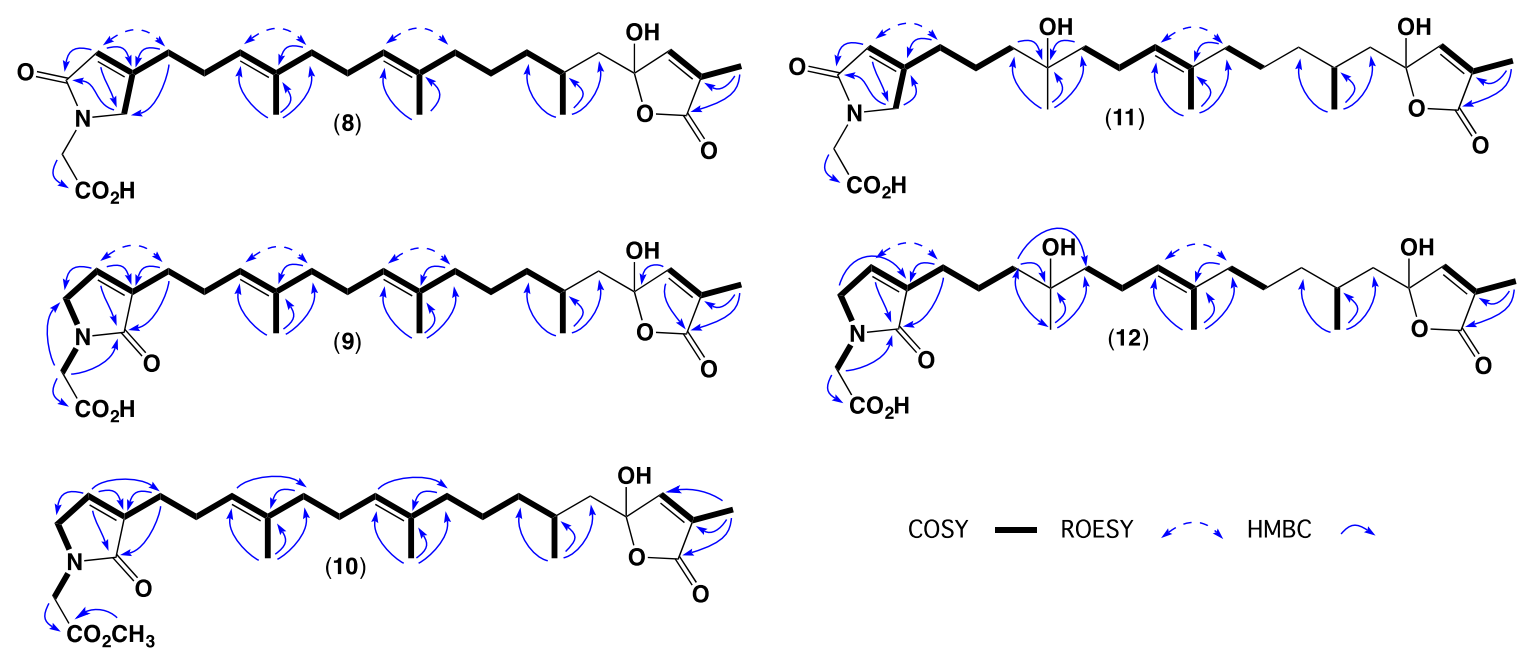

COSY ROESY $\rightleftharpoons$ HMBC $~$

Figure 6. Selected 2D NMR $\left(\mathrm{CDCl}_{3}\right)$ correlations for cacolides $\mathrm{H}-\mathrm{L}$ (8-12). 
Table 4. ${ }^{13} \mathrm{C}(150 \mathrm{MHz}) \mathrm{NMR}$ Data for $\mathbf{8}-\mathbf{1 5}$ in $\mathrm{CDCl}_{3}$.

\begin{tabular}{ccccccccc}
\hline Position & $\mathbf{8}$ & $\mathbf{9}$ & $\mathbf{1 0}$ & $\mathbf{1 1}$ & $\mathbf{1 2}$ & $\mathbf{1 3}$ & $\mathbf{1 4}$ & $\mathbf{1 5}$ \\
\hline 1 & 173.5 & 52.1 & 51.7 & 173.2 & 52.1 & 171.4 & 171.4 & 97.2 \\
2 & 121.0 & 136.9 & 136.0 & 121.5 & 136.9 & 118.0 & 118.0 & 143.9 \\
3 & 162.3 & 139.2 & 139.9 & 161.8 & 139.4 & 169.5 & 169.5 & 138.6 \\
4 & 55.7 & 173.3 & 173.1 & 55.6 & 173.0 & 99.3 & 99.3 & 172.3 \\
5 & 30.0 & 25.9 & 26.3 & 30.3 & 26.5 & 27.9 & 27.9 & 25.3 \\
6 & 26.0 & 26.0 & 26.1 & 22.3 & 22.3 & 25.3 & 25.3 & 25.6 \\
7 & 122.8 & 123.7 & 124.1 & $41.5^{\mathrm{a}}$ & $41.5^{\mathrm{a}}$ & 122.6 & 122.8 & 123.0 \\
8 & 136.8 & 135.9 & 135.6 & 72.7 & 73.4 & 137.3 & 137.0 & 137.3 \\
9 & 16.2 & 16.1 & 16.1 & 27.0 & 26.8 & 16.2 & 16.1 & 16.2 \\
10 & 39.6 & 39.5 & 39.6 & $41.5 \mathrm{a}$ & $41.5^{\mathrm{a}}$ & 39.4 & 39.4 & 39.6 \\
11 & 26.2 & 26.1 & 25.9 & 23.0 & 22.8 & 26.1 & 25.8 & 26.1 \\
12 & 124.1 & 124.3 & 124.2 & 125.0 & 125.1 & 124.1 & 124.1 & 124.4 \\
13 & 135.3 & 135.4 & 135.2 & 134.8 & 135.4 & 135.5 & 135.2 & 135.6 \\
14 & 16.1 & 16.0 & 16.0 & 16.1 & 15.9 & 16.1 & 16.1 & 16.2 \\
15 & 39.8 & 39.8 & 39.9 & 39.5 & 39.4 & 39.7 & 39.5 & 39.6 \\
16 & 25.1 & 25.1 & 25.1 & 24.7 & 24.5 & 25.2 & 25.6 & 25.6 \\
17 & 37.4 & 37.0 & 37.8 & 37.1 & 37.0 & 36.4 & 33.4 & 33.6 \\
18 & 28.6 & 29.1 & 28.8 & 28.6 & 28.5 & 29.7 & 39.2 & 39.1 \\
19 & 21.1 & 21.1 & 21.4 & 21.3 & 21.1 & 20.1 & 17.2 & 17.3 \\
20 & 44.8 & 44.8 & 44.9 & $44.9 \mathrm{~b}$ & 45.2 & 52.6 & 180.2 & 180.4 \\
21 & 107.5 & 107.5 & $\#$ & $\#$ & 107.8 & 202.9 & & \\
22 & 148.0 & 148.0 & 148.1 & 147.5 & 148.1 & 133.8 & & \\
23 & 131.7 & 131.7 & 132.0 & 132.0 & 131.7 & 140.5 & & \\
24 & 172.4 & 171.9 & 175.5 & 172.0 & 172.4 & 170.7 & & \\
25 & 10.8 & 10.6 & 10.7 & 10.6 & 10.8 & 14.4 & & \\
$1^{\prime}$ & 43.7 & 44.1 & 43.8 & 44.1 & 44.4 & & & \\
$2^{\prime}$ & 171.7 & 172.6 & 170.3 & 171.6 & 171.3 & & & \\
$1-$-OMe & & & 52.4 & & & & & \\
\hline
\end{tabular}

a Resonances with the same superscript within a column are interchangeable, ${ }^{\text {b }}$ Detected from HMBC, ${ }^{\#}$ Not detected.

HRESI(+)MS analysis of $\mathbf{1 3}$ revealed a sodium adduct ion attributed to a molecular formula $\left(\mathrm{C}_{25} \mathrm{H}_{36} \mathrm{O}_{6}, \Delta \mathrm{mmu}+0.7\right)$ isomeric with the co-metabolites 2 and 3 , with comparison of NMR $\left(\mathrm{CDCl}_{3}\right)$ data (Table 4, Table 6 and Table S12) confirming a common C-1 to C-19 structure fragment, inclusive of a C-1 to C-4 $\beta$-substituted $\gamma$-hydroxybutenolide and $E \Delta^{7}$ and $E \Delta^{12}$ moieties. Further NMR comparisons revealed that 13 lacked the characteristic C-21 to C-25 $\alpha$-methyl- $\gamma$-hydroxyl- $\gamma$ - substituted butenolide moiety common across cacolides A-L (1-12), in favour of an acyclic isomeric equivalent, featuring a ketone $\left(C-21, \delta_{C} 202.9\right)$ conjugated to a $\Delta^{22,23}\left(C-22, \delta_{C} 133.8 ; C-23, \delta_{C} 140.5\right)$ bearing methyl $(C-25$, $\left.\delta_{C} 14.4\right)$ and carboxylic acid $\left(C-24, \delta_{C} 170.7\right)$ moieties. The proposed C-21 to $C-25$ terminus was further confirmed by HMBC correlations from $\mathrm{H}-22$ to $\mathrm{C}-20$ and from $\mathrm{H}_{3}-25$ to C-22, C-23 and C-24 (Figure 7). An $E \Delta^{22}$ configuration was tentatively proposed on the basis that the alternate $Z$ configuration might be expected to undergo at least partial cyclisation to yield the butenolide moiety common across co-metabolites 1-12 (see biosynthetic discussion below). Based on the above, the planar structure for cacolic acid A (13) was assigned as shown (Figure 1). 
Table 5. ${ }^{1} \mathrm{H}(600 \mathrm{MHz})$ NMR Data for 8-12 in $\mathrm{CDCl}_{3}$.

\begin{tabular}{|c|c|c|c|c|c|}
\hline Position & $\stackrel{8}{\delta_{\mathrm{H}}, \mathrm{m}(J \text { in } \mathrm{Hz})}$ & $\begin{array}{c}9 \\
\delta_{\mathrm{H}}, \mathrm{m}(J \text { in } \mathrm{Hz})\end{array}$ & $\delta_{\mathrm{H}, \mathrm{m}}^{10}(J$ in $\mathrm{Hz})$ & $\delta_{\mathrm{H}}, \frac{11}{\mathrm{~m}(J \text { in } \mathrm{Hz})}$ & $\delta_{\mathrm{H}}, \mathrm{m}(J$ in $\mathrm{Hz})$ \\
\hline 1 & & 4.03, br s & 4.00 , br s & & 4.02, br s \\
\hline 2 & 5.91 , br s & 6.77 , br s & 6.74 , br s & 5.93 , br s & 6.78, br s \\
\hline 4 & 4.04, br s & & & 4.04, br s & \\
\hline 5 & $2.43, \mathrm{t}(7.5)$ & $2.30, \mathrm{t}(7.2)$ & $2.32, \mathrm{t}(7.2)$ & $2.40, \mathrm{t}(7.5)$ & $2.32, \mathrm{t}(7.5)$ \\
\hline 6 & $2.28, \mathrm{~m}$ & $2.24, \mathrm{dt}(7.3,7.3)$ & $2.25, \mathrm{dt}(7.3,7.3)$ & $1.66^{\mathrm{a}}, \mathrm{m}$ & $1.61, \mathrm{~m}$ \\
\hline 7 & 5.09, br t $(7.0)$ & 5.11, br t $(7.3)$ & 5.15, br t $(7.3)$ & $\begin{array}{l}\text { a } 1.54^{b} \\
\text { b } 1.52^{c}\end{array}$ & $\begin{array}{l}\text { a } 1.52^{\mathrm{a}} \\
\mathrm{b} 1.50^{\mathrm{b}}\end{array}$ \\
\hline 9 & $1.60, \mathrm{~s}$ & $1.59, \mathrm{~s}$ & $1.60, \mathrm{~s}$ & $1.19, \mathrm{~s}$ & $1.18, \mathrm{~s}$ \\
\hline 10 & $2.02, \mathrm{~m}$ & $2.01, \mathrm{t}(7.0)$ & $2.03, \mathrm{t}(7.0)$ & $\begin{array}{l}\text { a } 1.54^{b} \\
\text { b } 1.52^{c}\end{array}$ & $\begin{array}{l}\text { a } 1.52^{\mathrm{a}} \\
\mathrm{b} 1.50^{\mathrm{b}}\end{array}$ \\
\hline 11 & $2.09, \mathrm{~m}$ & $2.08, \mathrm{dt}(7.0,7.0)$ & $2.10, \mathrm{dt}(7.0,7.0)$ & $2.07, \mathrm{~m}$ & $2.05, \mathrm{~m}$ \\
\hline 12 & 5.04, brt $(7.0)$ & 5.04, br t $(7.0)$ & 5.06, br t $(7.0)$ & 5.15, brt $(7.0)$ & 5.14 , brt $(7.0)$ \\
\hline 14 & 1.56 , br s & $1.56, \mathrm{~s}$ & $1.56, \mathrm{~s}$ & 1.59, br s & 1.59, br s \\
\hline 15 & $1.92, \mathrm{~m}$ & $1.92, \mathrm{~m}$ & $1.93, \mathrm{~m}$ & $1.96, \mathrm{~m}$ & $1.95^{c}$ \\
\hline 16 & $1.36, \mathrm{~m}$ & $1.36, \mathrm{~m}$ & $1.37, \mathrm{~m}$ & $1.39, \mathrm{~m}$ & $1.39, \mathrm{~m}$ \\
\hline 17 & $\begin{array}{l}\text { a } 1.30, \mathrm{~m} \\
\text { b } 1.14, \mathrm{~m}\end{array}$ & $\begin{array}{l}\text { a } 1.27, \mathrm{~m} \\
\text { b } 1.13, \mathrm{~m}\end{array}$ & $\begin{array}{l}\text { a } 1.28, \mathrm{~m} \\
\text { b } 1.16, \mathrm{~m}\end{array}$ & $\begin{array}{l}\text { a } 1.32, \mathrm{~m} \\
\text { b } 1.11, \mathrm{~m}\end{array}$ & $\begin{array}{l}\text { a } 1.33, \mathrm{~m} \\
\text { b } 1.10, \mathrm{~m}\end{array}$ \\
\hline 18 & $1.64, \mathrm{~m}$ & $1.62, \mathrm{~m}$ & $1.64, \mathrm{~m}$ & $1.66^{\mathrm{a}}, \mathrm{m}$ & $1.65, \mathrm{~m}$ \\
\hline 19 & 0.94, br d $(7.0)$ & 0.94, br s & $0.95, \mathrm{br} \mathrm{s}$ & 0.94, br d (7.0) & 0.94, br d (7.0) \\
\hline 20 & $\begin{array}{l}\text { a } 1.95, \mathrm{~m} \\
\text { b } 1.70, \mathrm{~m}\end{array}$ & $\begin{array}{l}\text { a } 1.95, \mathrm{~m} \\
\text { b } 1.69, \mathrm{~m}\end{array}$ & $\begin{array}{l}\text { a } 2.00, \mathrm{~m} \\
\text { b } 1.71, \mathrm{~m}\end{array}$ & \# & $\begin{array}{c}\text { a } 1.95^{\mathrm{c}} \\
\text { b } 1.73, \mathrm{~m}\end{array}$ \\
\hline 22 & 6.82, br s & 6.83, br s & 6.83, br s & 6.81, br s & $6.83, \mathrm{~s}$ \\
\hline 25 & $1.90, \mathrm{~s}$ & $1.90, \mathrm{~s}$ & $1.91, \mathrm{~s}$ & $1.91, \mathrm{~s}$ & $1.90, \mathrm{~s}$ \\
\hline $\begin{array}{c}1^{\prime} \\
\text { 1-OMe }\end{array}$ & $\begin{array}{l}\text { a } 4.22, \mathrm{~m} \\
\text { b } 4.18, \mathrm{~m}\end{array}$ & $\begin{array}{l}\text { a } 4.28, \mathrm{~m} \\
\text { b } 4.25, \mathrm{~m}\end{array}$ & $\begin{array}{c}\text { a } 4.25, \mathrm{~m} \\
\text { b } 4.21, \mathrm{~m} \\
3.74, \mathrm{~s}\end{array}$ & 4.21 , br s & $4.23, \mathrm{~s}$ \\
\hline
\end{tabular}

${ }^{a-c}$ Resonances with the same superscript within a column are overlapping signals, ${ }^{\#}$ Not detected.

HRESI(+)MS analysis of $\mathbf{1 4}$ and $\mathbf{1 5}$ revealed a sodium adduct ions attributed to isomeric molecular formulae $\left(\mathrm{C}_{20} \mathrm{H}_{30} \mathrm{O}_{5}, \Delta \mathrm{mmu}-1.0\right.$ and -0.8 , respectively) requiring 6 double bond equivalents (DBE). Analysis of the NMR $\left(\mathrm{CDCl}_{3}\right)$ data for 14 (Table 4, Table 6 and Table S14) revealed resonances for a C-1 to C-19 structure fragment in common with 13, together with a carboxylic acid (C-20 $\left.\delta_{C} 180.2\right)$, accounting for all 6 DBE. Diagnostic 2D NMR correlations confirmed the regiochemistry of the C-1 to C-4 $\beta$-substituted $\gamma$-hydroxybutenolide moiety (Figure 7) and allowed assembly of the planar structure for cacolic acid B (14) as shown (Figure 1). Analysis of the NMR $\left(\mathrm{CDCl}_{3}\right)$ data for 15 (Table 4, Table 6 and Table S14) revealed resonances for a C-1 to C-19 structure fragment in common with 3, together with a carboxylic acid (C-20 $\delta_{C}$ 180.4), accounting for all 6 DBE. Diagnostic 2D NMR correlations confirmed the regiochemistry of the C-1 to C- $4 \alpha$-substituted $\gamma$-hydroxybutenolide moiety (Figure 7) and allowed assembly of the planar structure for cacolic acid C (15) as shown (Figure 1).

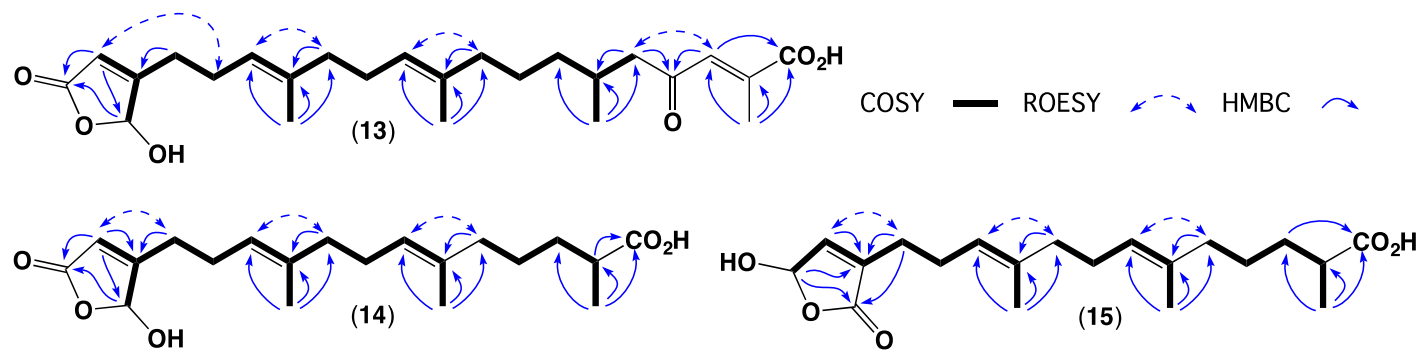

Figure 7. Selected 2D NMR $\left(\mathrm{CDCl}_{3}\right)$ correlations for cacolic acids A-C (13-15). 
Table 6. ${ }^{1} \mathrm{H}$ (600 MHz) NMR Data for 13-15 in $\mathrm{CDCl}_{3}$.

\begin{tabular}{|c|c|c|c|}
\hline Position & $\delta_{\mathrm{H}}, \mathrm{m}(J$ in $\mathrm{Hz})$ & $\begin{array}{c}14 \\
\delta_{\mathrm{H}}, \mathrm{m}(J \text { in } \mathrm{Hz})\end{array}$ & $\delta_{\mathrm{H}}, \mathrm{m}(J$ in $\mathrm{Hz})$ \\
\hline 1 & & & 6.09, br s \\
\hline 2 & 5.85 , br s & 5.88, br s & 6.84, br s \\
\hline 4 & 5.99 , br s & $6.01, \mathrm{br}$ & \\
\hline 5 & $2.46, \mathrm{~m}$ & $2.47^{\mathrm{a}}$ & $2.32, \mathrm{t}(7.3)$ \\
\hline 6 & $2.32, \mathrm{~m}$ & $2.33, \mathrm{~m}$ & $2.25, \mathrm{dt}(7.3,7.2)$ \\
\hline 7 & 5.09, brt $(7.3)$ & 5.10 , br t (7.3) & 5.09 br t $(7.2)$ \\
\hline 9 & 1.59, br s & $1.64^{\mathrm{b}}$, br s & $1.64^{\mathrm{a}}, \mathrm{s}$ \\
\hline 10 & $2.03^{\mathrm{a}}$ & $2.06, \mathrm{~m}$ & 2.02, br t $(7.0)$ \\
\hline 11 & $2.09(\mathrm{~m})$ & $2.12, \mathrm{~m}$ & $2.09, \mathrm{dt}(7.2,7.0)$ \\
\hline 12 & 5.03, brt $(7.0)$ & 5.06 , br t $(7.0)$ & 5.04, br t $(7.2)$ \\
\hline 14 & 1.57 , br s & 1.59, br s & $1.57, \mathrm{~s}$ \\
\hline 15 & $1.94, \mathrm{~m}$ & $1.98, \mathrm{~m}$ & $1.96, \mathrm{~m}$ \\
\hline 16 & $1.37, \mathrm{~m}$ & $1.42^{\mathrm{c}}$ & $1.42^{\mathrm{b}}$ \\
\hline 17 & a $1.25, \mathrm{~m}$ & a $1.64^{b}$ & a $1.64^{a}$ \\
\hline 18 & $\begin{array}{c}\text { b 1.15, m } \\
2.03^{a}\end{array}$ & $\begin{array}{c}\text { b } 1.42^{c} \\
2.47^{a}\end{array}$ & $\begin{array}{l}\mathrm{b} 1.42^{\circ} \\
2.47, \mathrm{~m}\end{array}$ \\
\hline 19 & 0.91, br d (6.7) & 1.19, br d (7.2) & 1.17, br d $(7.0)$ \\
\hline 20 & $\begin{array}{l}\text { a. } 2.53, \mathrm{~m} \\
\text { b. } 2.35, \mathrm{~m}\end{array}$ & & \\
\hline 22 & 7.11 , br s & & \\
\hline 25 & $2.20, \mathrm{~s}$ & & \\
\hline
\end{tabular}

All the metabolites 1-15 incorporate chiral $\mathrm{sp}^{3}$ centres, at one or both termini and are optically active (negative specific rotations). In an effort to assign absolute configurations we turned our attention to the likely biosynthetic relationship between 1-15. For the C-1 to C-4 termini we propose a relationship (Scheme 1) based around oxidative elaboration of the precursor $\beta$-substituted furanyl moiety in cacolide A (1). Mono-epoxidations lead to isomeric $\alpha, \beta$-unsaturated butyrolactones that in turn form adducts with glycine to yield the regioisomeric glycinyl-lactam pairs $\mathbf{9}$ and $\mathbf{1 2}$ and $\mathbf{8}$ and 11 [10]. In an alternate oxidative elaboration, $2+4$ addition of oxygen to the furan moiety (either stereospecific, or non-stereospecific) generates an intermediate cyclic peroxide, which undergoes alternate rearrangements to yield regioisomeric $\gamma$-hydroxybutenolides $(2,3,6$ and 13-15). These butenolides can undergo elimination/addition reactions to both racemize $\mathrm{sp}^{3} \mathrm{C}-1$ or C-4 chiral centres and yield OMe (4) and OEt (5 and 7) adducts, with the latter likely solvolysis artefacts generated during long term freezer storage of Cacospongia sp. (CMB-03404) in EtOH. The racemic character of natural sesterterpene $\gamma$-hydroxybutenolides is evident in other marine sponge metabolites, including manoalides [12-14], luffariellolides [15,16], luffariolides [17], acantholides [18], thorectidaeolides [19] and cacospongionolides [20], and in the case of 1-15 ensures that the C-1 to C-4 termini does not contribute to specific rotations.

Cacolides A-L (1-12) incorporate a common C-17 to C-25 terminus bearing chiral centres at C-18 and C-21, with spectroscopic and chromatographic data indicative of a single diastereomer. By comparison, cacolic acids $\mathrm{A}-\mathrm{C}(\mathbf{1 3}-\mathbf{1 5})$ feature an alternate terminus bearing a single $\mathrm{C}-18$ chiral centre. A plausible biosynthetic relationship between the C-17 to C-25 termini in 1-15 could see all derived from oxidation of a putative furan precursor (Scheme 2). This would proceed by stereospecific $2+4$ addition of oxygen to the furan moiety to yield a cyclic peroxide, followed by regiospecific rearrangement to yield the $\alpha$-methyl- $\gamma$-hydroxy- $\gamma$-substituted butenolide common to 1-12. Nucleophilic hydrolysis of the lactone heterocyclic would yield an acyclic 21-oxo $Z \Delta^{22}$ intermediate, which following double bond isomerization and hydrolysis would yield the 21-oxo $E$ $\Delta^{22}$ carboxylic acid 13. Further oxidative degradation of 13 would yield 14-15. In this relationship, the configurations about C-18 are preserved across 1-15 and about C-21 for 1-12. Comparison of the 
negative specific rotations for 14-15, with the known model compounds (-)-R-2,6-dimethyl-5-heptenoic acid [21,22] and (+)-S-2,6-dimethyl-5-heptenoic acid [22], suggests that 14-15 and by inference 1-13, possess an $18 R$ configuration. The absolute configuration about C-21 in 1-12 remains unassigned.

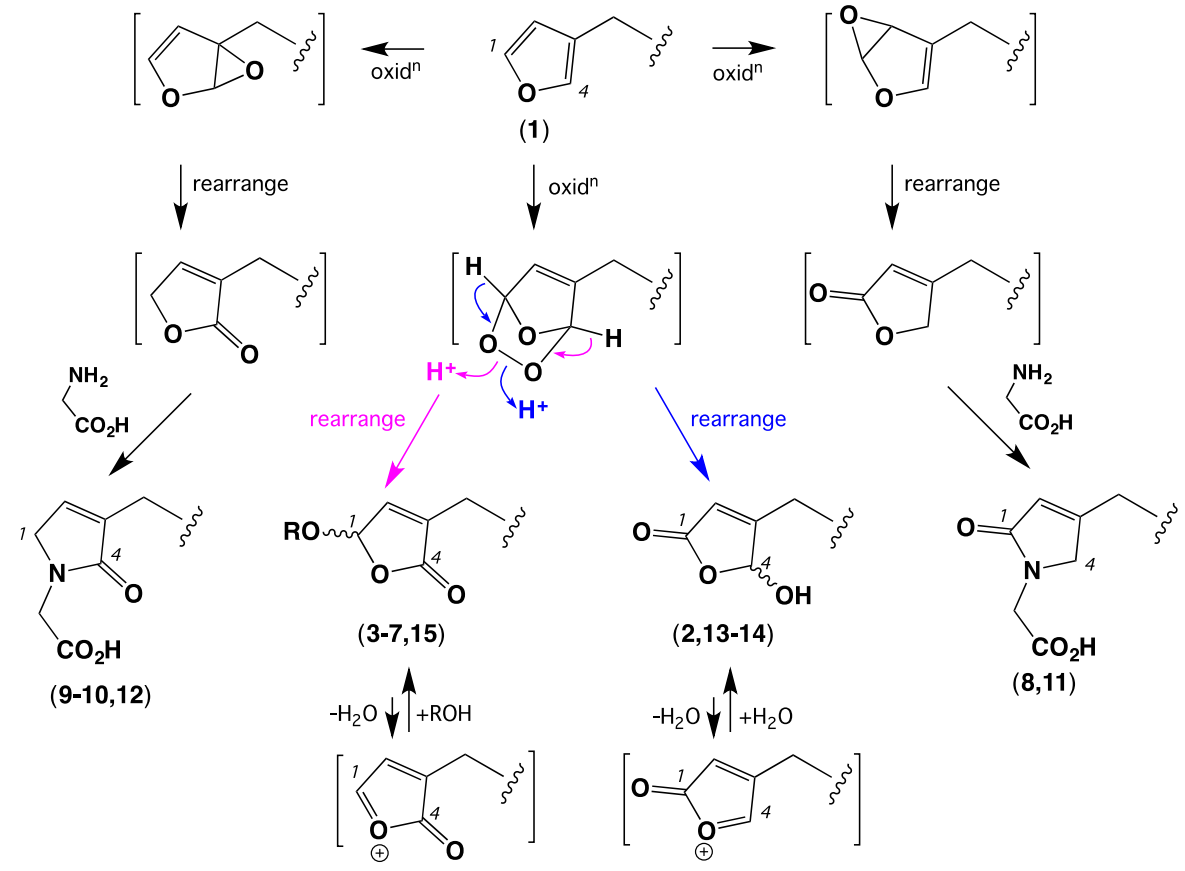

Scheme 1. Plausible biosynthetic relationship between the C-1 to C-4 termini in 1-15.

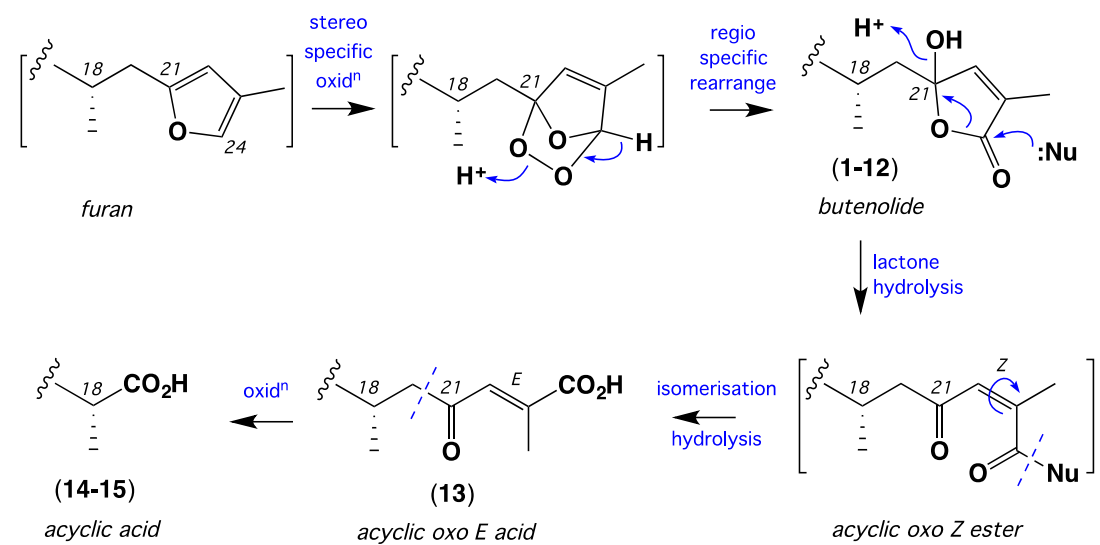

Scheme 2. Plausible biosynthetic relationship between the C-17 to C-25 termini in 1-15.

As predicted from screening of the Cacospongia sp. (CMB-03404) $n$-BuOH solubles, none of the pure metabolites 1-5 exhibited growth inhibitory activity against the Gram-positive bacterium Bacillus subtilis, Gram-negative bacterium Escherichia coli, a fungus Candida albicans, or two human cancer cell lines (SW620 and NCI-H460) at concentrations up to $30 \mu \mathrm{M}$. Furthermore, given the difficulties encountered in using HPLC-DAD, HPLC-MS and ${ }^{1} \mathrm{H}$ NMR dereplication on CMB-03404, we elected to investigate the application of Global Natural Product Social Molecular (GNPS) networking [23]. From our in-house library of southern Australian sponges, we acquired ultra-high perfomance liquid chromatography quadrupole time of flight, negative mode mass spectrometry (UPLC-QTOF-(-)MS/MS) data on $n$-BuOH solubles from $\times 5$ specimens each of Ircinia spp., Psammocinia spp. and Sarcotragus spp., along with authentic samples of $(7 E, 12 E, 20 Z, 18 S)$-variabilin (16) and ircinialactam A (20). A GNPS analysis of this data (Figures S3-S5) confirmed that all Ircinia, Psammocinia and Sarcotragus samples displayed a sesterterpene tetronic acid cluster, which incorporated 
the authentic standards $\mathbf{1 6}$ and $\mathbf{2 0}$ (and a number of related metabolites) (Figure 8A-C). By contrast, a GNPS analysis performed on $n$-BuOH solubles from Cacospongia sp. (CMB-03404) did not reveal a sesterterpene tetronic acid cluster (Figure S6), with the cacolides and cacolic acids dispersed over several clusters (Figure 8D).
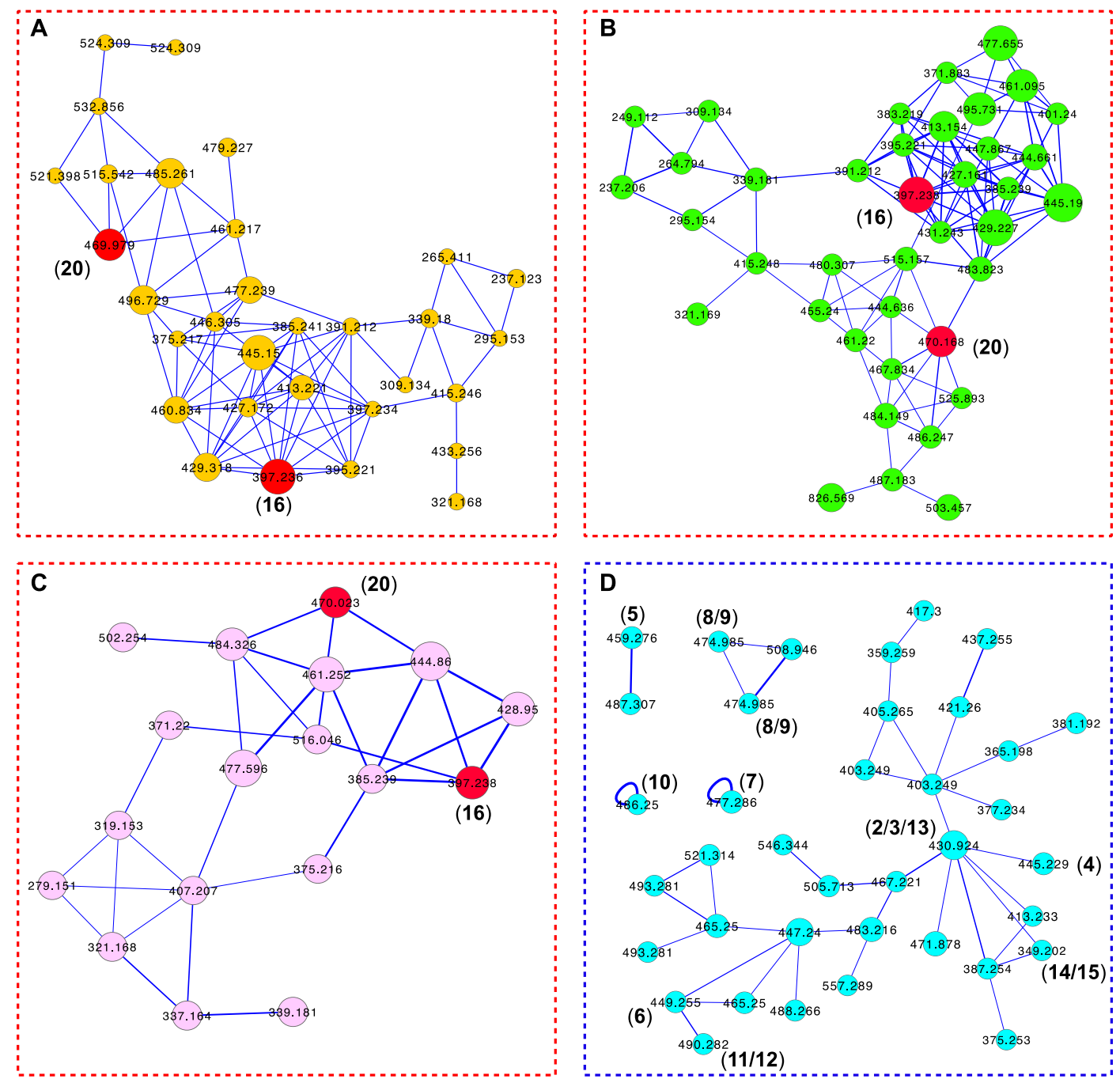

Figure 8. Molecular networking of $n-\mathrm{BuOH}$ solubles from (A) five specimens of Ircinia spp., (B) five specimens of Psammocinia spp., (C) five specimens of Sarcotragus spp. and (D) Cacospongia sp. (CMB-03404). Red nodes: the two authentic standards, (7E,12E,20Z,18S)-variabilin (16) and ircinialactam A (20).

Close inspection of the MS/MS data revealed that, unlike sesterterpene tetronic acids, the butenolides 1-15 were prone to the facile loss of $\mathrm{CO}_{2}$, with further fragmentations defined by differing degrees of oxygenation and substitution. These observations confirm that, while GNPS can be an effective tool to detect the presence of sesterterpene tetronic acids in crude extracts, it is less useful at detecting and cataloguing cacolides/cacolic acids. Our discovery of cacolides A-L (1-12) and cacolic acids A-C (13-15) provides an intriguing chapter in the knowledge of marine sponge natural products and highlights some of the challenges faced in applying traditional and even newer (i.e., GNPS), dereplication technologies. 


\section{Materials and Methods}

\subsection{General Experimental Procedures}

Optical rotation values $\left([\alpha]_{D}\right)$ were measured with a JASCO P-1010 polarimeter (JASCO International Co. Ltd., Tokyo, Japan) in a $100 \mathrm{~mm} \times 2 \mathrm{~mm}$ cell at room temperature. NMR spectra were recorded in $\mathrm{CDCl}_{3}$ on a Bruker Avance $600 \mathrm{MHz}$ spectrometer (Bruker Pty. Ltd., Alexandria, NSW, Australia) equipped with either a $5 \mathrm{~mm}$ PASEL ${ }^{1} \mathrm{H} / \mathrm{D}-{ }^{13} \mathrm{C}$ Z-Gradient probe or $5 \mathrm{~mm}$ CPTCI ${ }^{1} \mathrm{H} /{ }^{19} \mathrm{~F}-{ }^{13} \mathrm{C} /{ }^{15} \mathrm{~N} / \mathrm{DZ}-$ Gradient cryoprobe, controlled by TopSpin 2.1 software (Bruker Pty. Ltd., Alexandria, NSW, Australia). HRESI(+)-MS spectra were obtained on a Bruker micrOTOF mass spectrometer (Bruker Daltonik Pty. Ltd., Preston, VIC, Australia) by direct injection in MeCN at $3 \mu \mathrm{L} / \mathrm{min}$ using sodium formate clusters as an internal calibrant. UPLC-HRMS data were obtained on a quadrupole time-of-flight spectrometer (Agilent 6545 Q-TOF LC/MS) using a Zorbax SB-C 8 column $(150 \mathrm{~mm} \times 2.1 \mathrm{~mm}, 1.7 \mu \mathrm{m})$ (Agilent Technologies Inc., Mulgrave, VIC, Australia) with a linear gradient of $10-100 \% \mathrm{CH}_{3} \mathrm{CN}$ (with constant $0.1 \%$ formic acid as a modifier) at $0.45 \mathrm{~mL} / \mathrm{min}$ over $6.0 \mathrm{~min}$. HPLC-DAD-ESIMS data were acquired on an Agilent 1100 series separation module equipped with an Agilent 1100 series HPLC/MSD mass detector and diode array multiple wavelength detector (Agilent Technologies Inc., Mulgrave, VIC, Australia). Semi-preparative and preparative HPLCs were performed using Agilent 1100 series HPLC instruments with corresponding detectors, fraction collectors and software inclusively. All solvents used for HPLC separation and purification were chromatographic grade.

\subsection{Collection and Taxonomy}

Specimen CMB-03404 was collected in 2001 as by-catch during commercial fisheries operations (bottom trawling of Lucky S vessel) in the Great Australian Bight. The specimen was immediately frozen and transported at $0{ }^{\circ} \mathrm{C}$ to the laboratory, where it was thawed, documented, diced and stored in $\mathrm{EtOH}$ at $-30^{\circ} \mathrm{C}$ prior to chemical investigation. The specimen was taxonomically classified as a Cacospongia sp. (Class Demospongiae, Order Dictyoceratida, Family Thorectidae).

\subsection{Extraction and Fractionation}

A portion of the aqueous EtOH extract of Cacospongia sp. (CMB-03404) was decanted, concentrated in vacuo and the residue ( $4.5 \mathrm{~g}$ ) partitioned between $n-\mathrm{BuOH}$ and $\mathrm{H}_{2} \mathrm{O}$. The $n-\mathrm{BuOH}$ soluble material was concentrated in vacuo $(1.2 \mathrm{~g})$ and sequentially triturated and concentrated in vacuo to yield n-hexane (6.2 mg), DCM (550 mg), $\mathrm{MeOH}(500 \mathrm{mg})$ and $\mathrm{H}_{2} \mathrm{O}(31.8 \mathrm{mg})$ soluble materials. Following HPLC-DAD, UPLC-QTOF and ${ }^{1} \mathrm{H}$ NMR $\left(\mathrm{CDCl}_{3}\right)$ analysis, the DCM soluble material was selected for preparative HPLC (Agilent Zorbax SB-C $5 \mu \mathrm{m}, 21.2 \mathrm{~mm} \times 150 \mathrm{~mm}$ column, gradient elution at $20 \mathrm{~mL} / \mathrm{min}$ from $60 \% \mathrm{H}_{2} \mathrm{O} / \mathrm{MeCN}$ to $100 \% \mathrm{MeCN}$ over $40 \mathrm{~min}$, with an isocratic $0.01 \%$ TFA modifier) to yield 12 fractions (I-XII). Fraction IX was determined to be pure cacolide I (9) ( $t_{\mathrm{R}}=16.7 \mathrm{~min} ; 7.6 \mathrm{mg}$; $0.63 \%$ ). The remaining fractions were subjected to preparative HPLC fractionations using an Agilent Zorbax SB-C $5 \mu \mathrm{m}, 21.2 \mathrm{~mm} \times 150 \mathrm{~mm}$ column, with $20 \mathrm{~mL} / \mathrm{min}$ isocratic elution. Fraction II (isocratic $37 \% \mathrm{MeCN} / \mathrm{H}_{2} \mathrm{O}$ and $0.01 \%$ TFA over $\left.15 \mathrm{~min}\right)$ yielded cacolide $\mathrm{K}(\mathbf{1 1})\left(t_{\mathrm{R}}=13.1 \mathrm{~min} ; 0.9 \mathrm{mg} ; 0.08 \%\right)$ and cacolide L (12) $\left(t_{\mathrm{R}}=14.5 \mathrm{~min} ; 2.3 \mathrm{mg} ; 0.19 \%\right.$ ). Fraction III (isocratic $35 \% \mathrm{MeCN} / \mathrm{H}_{2} \mathrm{O}$ and $0.01 \% \mathrm{TFA}$ over $36 \mathrm{~min}$ ) yielded cacolide $\mathrm{F}(6)\left(t_{\mathrm{R}}=31.9 \mathrm{~min} ; 1.6 \mathrm{mg} ; 0.13 \%\right.$ ). Fraction V (isocratic $45 \% \mathrm{MeCN} / \mathrm{H}_{2} \mathrm{O}$ and $0.01 \%$ TFA over $30 \mathrm{~min}$ ) yielded cacolic acid B (14) ( $\left.t_{\mathrm{R}}=17.3 \mathrm{~min} ; 1 \mathrm{mg} ; 0.08 \%\right)$, cacolic acid C (15) $\left(t_{\mathrm{R}}=18.7 \mathrm{~min} ; 0.6 \mathrm{mg} ; 0.06 \%\right)$ and cacolide $\mathrm{H}(8)\left(t_{\mathrm{R}}=22.2 \mathrm{~min} ; 3.6 \mathrm{mg} ; 0.3 \%\right)$. Fraction VI (isocratic $60 \% \mathrm{MeCN} / \mathrm{H}_{2} \mathrm{O}$ and $0.01 \%$ TFA over $\left.28 \mathrm{~min}\right)$ yielded cacolide $\mathrm{G}(7)\left(t_{\mathrm{R}}=15.2 \mathrm{~min} ; 0.8 \mathrm{mg} ; 0.07 \%\right)$, cacolide B (2) ( $\left.t_{\mathrm{R}}=20.2 \mathrm{~min} ; 11.1 \mathrm{mg} ; 0.93 \%\right)$, cacolide C (3) $\left(t_{\mathrm{R}}=22.2 \mathrm{~min} ; 11.9 \mathrm{mg} ; 0.99 \%\right)$ and cacolic acid A (13) $\left(t_{\mathrm{R}}=26.8 \mathrm{~min} ; 2 \mathrm{mg} ; 0.17 \%\right.$ ). Fraction VIII (isocratic $65 \% \mathrm{MeCN} / \mathrm{H}_{2} \mathrm{O}$ and $0.01 \%$ TFA over $15 \mathrm{~min})$ yielded cacolide $\mathrm{D}(4)\left(t_{\mathrm{R}}=13.3 \mathrm{~min} ; 1 \mathrm{mg} ; 0.08 \%\right)$ and cacolide $\mathrm{E}(5)\left(t_{\mathrm{R}}=16.9 \mathrm{~min}\right.$; $9.3 \mathrm{mg} ; 0.78 \%$ ). Fraction $\mathrm{X}$ (isocratic $75 \% \mathrm{MeCN} / \mathrm{H}_{2} \mathrm{O}$ and $0.01 \%$ TFA over $15 \mathrm{~min}$ ) yielded cacolide A (1) $\left(t_{\mathrm{R}}=13.9 \mathrm{~min} ; 9 \mathrm{mg} ; 0.75 \%\right)$. Although only present in negligible amounts in the DCM solubles, 
preparative HPLC (gradient elution from $30 \% \mathrm{H}_{2} \mathrm{O} / \mathrm{MeCN}$ to $100 \% \mathrm{MeCN}$ over 25 min, with an isocratic $0.01 \%$ TFA modifier) fractionation of the $\mathrm{MeOH}$ solubles yielded cacolide $\mathrm{J}(\mathbf{1 0})\left(t_{\mathrm{R}}=14.2 \mathrm{~min}\right.$; $1.6 \mathrm{mg} ; 0.13 \%$ ) (see Figures S1 and S2).

\subsection{Metabolite Characterization}

Cacolide A (1). light yellow oil; $[\alpha]_{\mathrm{D}}^{25}-6.7(c$ 0.60, $\mathrm{MeOH})$; NMR (600 MHz, $\left.\mathrm{CDCl}_{3}\right)$ see Table S1 and Figures S4 and S5; HRESIMS $m / z$ 423.2511 [M + Na] ${ }^{+}$(calcd for $\mathrm{C}_{25} \mathrm{H}_{36} \mathrm{O}_{4} \mathrm{Na}, 423.2506$ ).

Cacolide B (2). light yellow oil; $[\alpha]_{\mathrm{D}}^{25}-5.3\left(\right.$ c 0.74, MeOH); NMR (600 MHz, $\left.\mathrm{CDCl}_{3}\right)$ see Table S2 and Figures S6 and S7; HRESIMS $m / z$ 455.2411 [M + Na] ${ }^{+}$(calcd for $\mathrm{C}_{25} \mathrm{H}_{36} \mathrm{O}_{6} \mathrm{Na}, 455.2404$ ).

Cacolide C (3). light yellow oil; $[\alpha]_{\mathrm{D}}^{25}-6.9$ ( $c 0.79$, $\left.\mathrm{MeOH}\right)$; $\mathrm{NMR}\left(600 \mathrm{MHz}, \mathrm{CDCl}_{3}\right)$ see Table $\mathrm{S} 3$ and Figures S8-S10; HRESIMS $m / z 455.2398$ [M + Na] ${ }^{+}$(calcd for $\mathrm{C}_{25} \mathrm{H}_{36} \mathrm{O}_{6} \mathrm{Na}, 455.2404$ ).

Cacolide D (4). light yellow oil; $[\alpha]_{\mathrm{D}}^{25}-20.9$ ( $c$ 0.06, $\left.\mathrm{MeOH}\right)$; NMR (600 MHz, $\left.\mathrm{CDCl}_{3}\right)$ see Table $\mathrm{S} 4$ and Figures S11 and S12; HRESIMS $m / z 469.2559[\mathrm{M}+\mathrm{Na}]^{+}$(calcd for $\mathrm{C}_{26} \mathrm{H}_{38} \mathrm{O}_{6} \mathrm{Na}, 469.2561$ ).

Cacolide E (5). light yellow oil; $[\alpha]_{\mathrm{D}}^{25}-6.9$ ( $\left.0.62, \mathrm{MeOH}\right)$; $\mathrm{NMR}\left(600 \mathrm{MHz}, \mathrm{CDCl}_{3}\right)$ see Table $\mathrm{S} 5$ and Figures S13 and S14; HRESIMS m/z $483.2725[\mathrm{M}+\mathrm{Na}]^{+}$(calcd for $\mathrm{C}_{27} \mathrm{H}_{40} \mathrm{O}_{6} \mathrm{Na}$, 483.2717).

Cacolide F (6). light yellow oil; $[\alpha]_{\mathrm{D}}^{25}-7.1($ c 0.08, $\mathrm{MeOH})$; NMR $\left(600 \mathrm{MHz}, \mathrm{CDCl}_{3}\right)$ see Table $\mathrm{S} 6$ and Figure S15; HRESIMS $m / z 473.2521$ [M + Na] ${ }^{+}$(calcd for $\left.\mathrm{C}_{25} \mathrm{H}_{38} \mathrm{O}_{7} \mathrm{Na}, 473.2510\right)$.

Cacolide G (7). light yellow oil; $[\alpha]_{\mathrm{D}}^{25}-15.1$ ( $c$ $\left.0.05, \mathrm{MeOH}\right)$; NMR (600 MHz, $\left.\mathrm{CDCl}_{3}\right)$ see Table $\mathrm{S} 7$ and Figures S16-S17; HRESIMS $m / z 501.2817[\mathrm{M}+\mathrm{Na}]^{+}$(calcd for $\mathrm{C}_{27} \mathrm{H}_{42} \mathrm{O}_{7} \mathrm{Na}$, 501.2823).

Cacolide $\mathrm{H}$ (8). light yellow oil; $[\alpha]_{\mathrm{D}}^{25}-5.0(c 0.24, \mathrm{MeOH})$; NMR $\left(600 \mathrm{MHz}, \mathrm{CDCl}_{3}\right)$ see Table $\mathrm{S} 8$ and Figures S18 and S19; HRESIMS $m / z 496.2678[\mathrm{M}+\mathrm{Na}]^{+}$(calcd for $\mathrm{C}_{27} \mathrm{H}_{39} \mathrm{NO}_{6} \mathrm{Na}, 496.2678$ ).

Cacolide I (9). light yellow oil; $[\alpha]^{25} \mathrm{D}-8.1(c 0.47, \mathrm{MeOH})$; $\mathrm{NMR}\left(600 \mathrm{MHz}, \mathrm{CDCl}_{3}\right)$ see Table S9 and Figures S20 and S21; HRESIMS $m / z$ 496.2682 [M + Na] ${ }^{+}$(calcd for $\mathrm{C}_{27} \mathrm{H}_{39} \mathrm{NO}_{6} \mathrm{Na}$, 496.2670).

Cacolide J (10). light yellow oil; $[\alpha]_{\mathrm{D}}^{25}-7.6\left(\right.$ c 0.11, MeOH); NMR (600 MHz, $\left.\mathrm{CDCl}_{3}\right)$ see Table $\mathrm{S} 10$ and Figures S22 and S23; HRESIMS $m / z 510.2827[\mathrm{M}+\mathrm{Na}]^{+}$(calcd for $\mathrm{C}_{28} \mathrm{H}_{41} \mathrm{NO}_{6} \mathrm{Na}, 510.2826$ ).

Cacolide K (11). light yellow oil; $[\alpha]_{\mathrm{D}}^{25}-4.7$ ( $\left.0.05, \mathrm{MeOH}\right)$; NMR $\left(600 \mathrm{MHz}, \mathrm{CDCl}_{3}\right)$ see Table S11 and Figure S24; HRESIMS m/z 514.2762 [M + Na] ${ }^{+}$(calcd for $\mathrm{C}_{27} \mathrm{H}_{41} \mathrm{NO}_{7} \mathrm{Na}$, 514.2775).

Cacolide L (12). light yellow oil; $[\alpha]_{\mathrm{D}}^{25}-6.9$ ( $\left.c 0.15, \mathrm{MeOH}\right)$; NMR $\left(600 \mathrm{MHz}, \mathrm{CDCl}_{3}\right)$ see Table $\mathrm{S} 12$ and Figures S25 and S26; HRESIMS $m / z 514.2789[\mathrm{M}+\mathrm{Na}]^{+}$(calcd for $\mathrm{C}_{27} \mathrm{H}_{41} \mathrm{NO}_{7} \mathrm{Na}, 514.2775$ ).

Cacolic acid A (13). light yellow oil; $[\alpha]_{D}^{25}-12.3$ ( c 0.13, MeOH); NMR (600 MHz, $\mathrm{CDCl}_{3}$ ) see Table $\mathrm{S} 13$ and Figures S27-S29; HRESIMS $m / z 455.2397[\mathrm{M}+\mathrm{Na}]^{+}$(calcd for $\mathrm{C}_{25} \mathrm{H}_{36} \mathrm{O}_{6} \mathrm{Na}$, 455.2404).

Cacolic acid B (14). light yellow oil; $[\alpha]_{\mathrm{D}}^{25}-7.5(c 0.07, \mathrm{MeOH})$; NMR $\left(600 \mathrm{MHz}, \mathrm{CDCl}_{3}\right)$ see Table $\mathrm{S} 14$ and Figures S30 and S31; HRESIMS m/z $373.1995[\mathrm{M}+\mathrm{Na}]^{+}$(calcd for $\mathrm{C}_{20} \mathrm{H}_{30} \mathrm{O}_{5} \mathrm{Na}$, 373.1985).

Cacolic acid C (15). light yellow oil; $[\alpha]_{\mathrm{D}}^{25}-32.2$ (c 0.04, $\left.\mathrm{MeOH}\right)$; NMR (600 MHz, $\mathrm{CDCl}_{3}$ ) see Table S15 and Figures S32 and S33; HRESIMS m/z $373.1993[\mathrm{M}+\mathrm{Na}]^{+}\left(\right.$calcd for $\left.\mathrm{C}_{20} \mathrm{H}_{30} \mathrm{O}_{5} \mathrm{Na}, 373.1985\right)$.

\subsection{Cytotoxicity Assay}

Adherent human colorectal (SW620) and lung (NCI-H460) carcinoma cells were cultured in Roswell Park Memorial Institute (RPMI) medium 1640. All cells were cultured as adherent mono-layers in flasks supplemented with $10 \%$ foetal bovine serum, L-glutamine $(2 \mathrm{mM})$, penicillin $(100 \mathrm{unit} / \mathrm{mL})$ and streptomycin $(100 \mu \mathrm{g} / \mathrm{mL})$, in a humidified $37^{\circ} \mathrm{C}$ incubator supplied with $5 \% \mathrm{CO}_{2}$. Briefly, cells were harvested with trypsin and dispensed into 96-well microtiter assay plates at 2000-5000 cells/well after which they were incubated for $18 \mathrm{~h}$ at $37^{\circ} \mathrm{C}$ with $5 \% \mathrm{CO}_{2}$ (to allow cells to attach as adherent mono-layers). Test compounds were dissolved in $20 \%$ DMSO in PBS $(v / v)$ and aliquots $(10 \mu \mathrm{L})$ applied 
to cells over a series of final concentrations ranging from $10 \mathrm{nM}$ to $30 \mu \mathrm{M}$. After $48 \mathrm{~h}$ incubation at $37^{\circ} \mathrm{C}$ with $5 \% \mathrm{CO}_{2}$ an aliquot $(20 \mu \mathrm{L})$ of (3-(4,5-dimethylthiazol-2-yl)-2,5-diphenyltetrazolium bromide (MTT) in phosphate buffered saline (PBS) $(5 \mathrm{mg} / \mathrm{mL}$ ) was added to each well (final concentration $0.5 \mathrm{mg} / \mathrm{mL}$ ) and microtiter plates were incubated for a further $4 \mathrm{~h}$ at $37^{\circ} \mathrm{C}$ with $5 \% \mathrm{CO}_{2}$. After final incubation, the medium was aspirated and precipitated formazan crystals dissolved in DMSO (100 $\mu \mathrm{L} /$ well). The absorbance of each well was measured at $580 \mathrm{~nm}$ with a PowerWave XS Microplate Reader from Bio-Tek Instruments Inc. (Vinooski, VT, USA). IC $_{50}$ values were calculated using Prism 7.0 (GraphPad Software Inc., La Jolla, CA, USA), as the concentration of analyte required for $50 \%$ inhibition of cancer cell growth (compared to negative controls). Negative control comprised of $1 \%$ aqueous DMSO, while positive control was doxorubicin. All experiments were performed in duplicate.

\subsection{Antibacterial Assay}

The bacterium to be tested was streaked onto a tryptic soy agar plate and incubated at $37{ }^{\circ} \mathrm{C}$ for $24 \mathrm{~h}$. One colony was then transferred to fresh tryptic soy broth $(15 \mathrm{~mL})$ and the cell density adjusted to $10^{4}-10^{5} \mathrm{CFU} / \mathrm{mL}$. The compounds to be tested were dissolved in DMSO and diluted with $\mathrm{H}_{2} \mathrm{O}$ to return $600 \mu \mathrm{M}$ stock solutions (20\% DMSO). The stock solutions were serially diluted to give concentration range of $600 \mu \mathrm{M}$ to $0.2 \mu \mathrm{M}$ in $20 \% \mathrm{DMSO} / \mathrm{H}_{2} \mathrm{O}$. An aliquot $(10 \mu \mathrm{L})$ of each dilution was transferred to a 96-well microtiter plate and freshly prepared microbial broth $(190 \mu \mathrm{L})$ was added to each well. The plates were incubated at $37^{\circ} \mathrm{C}$ for $24 \mathrm{~h}$ and the optical density of each well was measured spectrophotometrically at $600 \mathrm{~nm}$ using POLARstar Omega plate (BMG LABTECH, Offenburg, Germany). Each test compound was screened against the Gram-negative bacterium Escherichia coli (ATCC 11775) and the Gram-positive bacterium Bacillus subtilis (ATCC 6051). Rifampicin was used as a positive control $(40 \mu \mathrm{g} / \mathrm{mL}$ in $10 \% \mathrm{DMSO})$. The $\mathrm{IC}_{50}$ value was calculated as the concentration of the compound or antibiotic required for 50\% inhibition of the bacterial cells using Prism 7.0 from GraphPad Software Inc. (La Jolla, CA, USA).

\subsection{Antifungal Assay}

The fungus to be tested was streaked onto a sabouraud agar plate and incubated at $37{ }^{\circ} \mathrm{C}$ for $24 \mathrm{~h}$. One colony was then transferred to fresh sabouraud broth (15 $\mathrm{mL})$ and the cell density adjusted to $10^{4}-10^{5} \mathrm{CFU} / \mathrm{mL}$. The compounds to be tested were dissolved in DMSO and diluted with $\mathrm{H}_{2} \mathrm{O}$ to return $600 \mu \mathrm{M}$ stock solutions (20\% DMSO). The stock solutions were serially diluted to give concentration range of $600 \mu \mathrm{M}$ to $0.2 \mu \mathrm{M}$ in $20 \% \mathrm{DMSO} / \mathrm{H}_{2} \mathrm{O}$. An aliquot $(10 \mu \mathrm{L})$ of each dilution was transferred to a 96-well microtiter plate and freshly prepared microbial broth (190 $\mu \mathrm{L})$ was added to each well. The plates were incubated at $37^{\circ} \mathrm{C}$ for $24 \mathrm{~h}$ and the optical density of each well was measured spectrophotometrically at $600 \mathrm{~nm}$ using POLARstar Omega plate (BMG LABTECH, Offenburg, Germany). Each test compound was screened against Candida albicans (ATCC 10231). Nystatin was used as a positive control ( $40 \mu \mathrm{g} / \mathrm{mL}$ in $10 \%$ DMSO). The $\mathrm{IC}_{50}$ value was calculated as the concentration of the compound or antibiotic required for 50\% inhibition of the bacterial cells using Prism 7.0 from GraphPad Software Inc. (La Jolla, CA, USA).

\subsection{Global Natural Product Social Molecular Networking (GNPS)}

A series of GNPS analysis were carried out on UPLC-QTOF-(-)MS/MS data acquired on the n-BuOH solubles from; (A) Cacospongia sp. (CMB-03404); (B) Ircinia sp. (CMB-01064) known to produce (7E,12E,20Z,18S)-variabilin (16), (7E,12Z,20Z,18S)-variabilin (17), (12E,20Z,18S)-8-hydroxyvariabilin (18), ircinialactam A (20), 8-hydroxyircinialactam B (21) and 8-hydroxyircinialactam A (22) [6]; (C) Ircinia sp. (CMB-03363) known to produce 16-20 [6]; (D) Ircinia spp. CMB-01058, CMB-01693 and CMB-02014 that have not been subjected to detailed chemical analysis; (E) Psammocinia sp. (CMB-03231) known to produce ent-ircinialactam C [6]; (F) Psammocinia sp. (CMB-01018) known to produce 16-17 and 20, as well as ircinialactams C and G-I, ircinialactone A, irciniafuran A, (7Z,12Z,20Z,18S)-variabilin and (7Z,12E,20Z,18S)-variabilin [10]; (G) Psammocinia sp. (CMB-03344) known to produce (-)-ircinianin, 
(-)-ircinianin sulphate, (-)-oxoircinianin, (-)-ircinianin lactam A [7]; (H) Psammocinia spp. CMB-01757 and CMB-02026 that have not been subjected to detailed chemical analysis; (I) Sarcotragus spp. CMB-01788, CMB-01848, CMB-02707, CMB-02717 and CMB-03390 that have not been subjected to detailed chemical analysis; and (J) authentic standards of $(7 E, 12 E, 20 Z, 18 S)$-variabilin (16) and ircinialactam A (20). To acquire this data, aliquots $(1 \mu \mathrm{L}$ of $100 \mu \mathrm{g} / \mathrm{mL}$ in $100 \mu \mathrm{L} \mathrm{MeOH})$ of test solutions were analysed on an Agilent 6545 Q-TOF LC/MS equipped with an Agilent 1290 infinity II UPLC system, utilising an Agilent SB-C $81.8 \mu \mathrm{m}, 2.1 \times 50 \mathrm{~mm}$ column, with a $0.5 \mathrm{~mL} / \mathrm{min}, 4.5 \mathrm{~min}$ gradient elution from $90 \% \mathrm{H}_{2} \mathrm{O} / \mathrm{CH}_{3} \mathrm{CN}$ to $\mathrm{CH}_{3} \mathrm{CN}$, followed by isocratic elution with $\mathrm{CH}_{3} \mathrm{CN}$ for $1 \mathrm{~min}$, with a constant isocratic $0.1 \%$ formic acid modifier. UPLC-QTOF-(-)MS/MS data acquired for all samples at a fixed collision energy of $40 \mathrm{eV}$, were converted from Agilent MassHunter data files (.d) to mzXML file format and transferred to the GNPS server (gnps.ucsd.edu). Molecular networking was performed using the GNPS data analysis workflow using the spectral clustering algorithm and a cosine score of 0.7 and a minimum of 6 matched peaks. The resulting spectral networks were imported into Cytoscape version 3.5.1 (cytoscape.org) [24], where nodes represented parent (-) $\mathrm{m} / \mathrm{z}$ and edge thickness corresponded to cosine scores. Separate GNPS cluster maps were generated for (I) all $\times 5$ Ircinia spp. (Figure S3), (II) all $\times 5$ Psammocinia spp. (Figure S4) and (III) all $\times 5$ Sarcotragus spp. (Figure S5), compared against the authentic standards 16 and 20; and for (IV) Cacospongia sp. (CMB-03404) compared against data for Ircinia sp. (CMB-01064) and Ircinia sp. (CMB-03363) (Figure S6). In each case sesterterpene tetronic acid and cacolide/cacolic acid clusters are highlighted, as are the nodes for the authentic standards.

Supplementary Materials: The following are available online at http:/ /www.mdpi.com/1660-3397/16/11/456/ s1, HPLC chromatogram and fractionation scheme, full molecular network (GNPS) analyses, tabulated 1D and 2D NMR data, annotated 1D NMR and selected 2D NMR spectra and bioassay data (pdf).

Author Contributions: R.J.C. conceptualized the research and assembled the marine sponge collection; S.K. carried out the isolation and spectroscopic characterization of Cacospongia natural products and performed dereplication and GPNS analyses; L.N. performed bioassays; A.A.S. and S.K. assigned molecular structures to the Cacospongia natural products and constructed the Supplementary Materials document; R.J.C. reviewed all data and drafted the manuscript, with support from S.K. and A.A.S.

Funding: This research was supported in part by The University of Queensland and the Institute for Molecular Bioscience.

Acknowledgments: We thank the crew and owners of the fishing vessel Lucky S for the collection of sponge samples and L Goudie for sponge identifications. S.K. and L.N. thank The University of Queensland for postgraduate scholarships.

Conflicts of Interest: The authors declare no conflict of interest.

\section{References}

1. Perry, N.B.; Battershill, C.N.; Blunt, J.W.; Fenwick, G.D.; Munro, M.H.G.; Berquist, P.R. Occurrence of variabilin in New Zealand sponges of the order Dictyoceratida. Biochem. Syst. Ecol. 1987, 15, 373-376. [CrossRef]

2. Cimino, G.; De Stefano, S.; Minale, L.; Fattorusso, E. Ircinin-1 and -2, linear sesterterpenes from the marine sponge Ircinia oros. Tetrahedron 1972, 28, 333-341. [CrossRef]

3. Faulkner, D.J. Variabilin, an antibiotic from the sponge Ircinia variabilis. Tetrahedron Lett. 1973, 14, 3821-3822. [CrossRef]

4. Capon, R.J.; Dargaville, T.R.; Davis, R. The absolute stereochemistry of variabilin and related sesterterpene tetronic acids. Nat. Prod. Lett. 1994, 4, 51-56. [CrossRef]

5. Capon, R.J.; MacLeod, J.K. A new sesterterpene tetronic acid from an Australian sponge, Ircinia sp. Aust. J. Chem. 1987, 40, 1327-1330. [CrossRef]

6. Balansa, W.; Islam, R.; Fontaine, F.; Piggott, A.M.; Zhang, H.; Webb, T.I.; Gilbert, D.F.; Lynch, J.W.; Capon, R.J. Ircinialactams: Subunit-selective glycine receptor modulators from Australian sponges of the family Irciniidae. Bioorg. Med. Chem. 2010, 18, 2912-2919. [CrossRef] [PubMed] 
7. Balansa, W.; Islam, R.; Fontaine, F.; Piggott, A.M.; Zhang, H.; Xiao, X.; Webb, T.I.; Gilbert, D.F.; Lynch, J.W.; Capon, R.J. Sesterterpene glycinyl-lactams: a new class of glycine receptor modulator from Australian marine sponges of the genus Psammocinia. Org. Biomol. Chem. 2013, 11, 4695-4701. [CrossRef] [PubMed]

8. Murray, L.; Hamit, H.; Hooper, J.N.A.; Hobbs, L.; Capon, R.J. A new sesterterpene tetronic acid from an Australian marine sponge, Psammocinia sp. Aust. J. Chem. 1995, 48, 1899-1902. [CrossRef]

9. Davis, R.; Capon, R.J. Two for one: structure revision of the marine sesterterpene tetronic acid strobilinin to (8Z,13E,20Z)-strobilinin and (8E,13E,20Z)-strobilinin. Aust. J. Chem. 1994, 47, 933-936. [CrossRef]

10. Prasad, P.; Zhang, A.; Salim, A.A.; Capon, R.J. Pursuing sesterterpene lactams in Australian Irciniidae sponges. Fitoterapia 2018, 126, 83-89. [CrossRef] [PubMed]

11. Barrow, C.J.; Blunt, J.W.; Munro, M.H.G.; Perry, N.B. Variabilin and related compounds from a sponge of the genus Sarcotragus. J. Nat. Prod. 1988, 51, 275-281. [CrossRef]

12. Potts, B.C.M.; Faulkner, D.J.; Capon, R.J. Luffalactone and $(4 E, 6 E)$-dehydromanoalide from the sponge Luffariella variabilis. J. Org. Chem. 1992, 57, 2965-2967. [CrossRef]

13. Zhou, G.-X.; Molinski, T.F. Manoalide derivatives from a sponge, Luffariella sp. J. Asian Nat. Prod. Res. 2006, 8, 15-20. [CrossRef] [PubMed]

14. Pommier, A.; Stepanenko, V.; Jarowicki, K.; Kocienski, P.J. Synthesis of (+)-manoalide via a copper(I)-mediated 1,2-metalate rearrangement. J. Org. Chem. 2003, 68, 4008-4013. [CrossRef] [PubMed]

15. Albizati, K.F.; Holman, T.; Faulkner, D.J.; Glaser, K.B.; Jacobs, R.S. Luffariellolide, an anti-inflammatory sesterterpene from the marine sponge Luffariella sp. Experientia 1987, 43, 949-950. [CrossRef]

16. Boukouvalas, J.; Robichaud, J.; Maltais, F. A unified strategy for the regiospecific assembly of homoallyl-substituted butenolides and $\gamma$-hydroxybutenolides: First synthesis of luffariellolide. Synlett 2006, 15, 2480-2482. [CrossRef]

17. Tsuda, M.; Endo, T.; Mikami, Y.; Fromont, J.; Kobayashi, J. Luffariolides H and J, new sesterterpenes from a marine sponge Luffariella species. J. Nat. Prod. 2002, 65, 1507-1508. [CrossRef] [PubMed]

18. Elkhayat, E.; Edrada, R.; Ebel, R.; Wray, V.; van Soest, R.; Wiryowidagdo, S.; Mohamed, M.H.; Müller, W.E.G.; Proksch, P. New luffariellolide derivatives from the Indonesian sponge Acanthodendrilla sp. J. Nat. Prod. 2004, 67, 1809-1817. [CrossRef] [PubMed]

19. Li, J.; Du, L.; Kelly, M.; Zhou, Y.-D.; Nagle, D.G. Structures and potential antitumor activity of sesterterpenes from the marine sponge Hyrtios communis. J. Nat. Prod. 2013, 76, 1492-1497. [CrossRef] [PubMed]

20. Cheung, A.K.; Murelli, R.; Snapper, M.L. Total syntheses of (+)- and (-)-cacospongionolide B, cacospongionolide E, and related analogues. Preliminary study of structural features required for phospholipase A2 inhibition. J. Org. Chem. 2004, 69, 5712-5719. [CrossRef] [PubMed]

21. Flachsbarth, B.; Fritzsche, M.; Weldon, P.J.; Schulz, S. Composition of the cloacal gland secretion of tuatara, Sphenodon punctatus. Chem. Biodiv. 2009, 6, 1-37. [CrossRef] [PubMed]

22. Burger, B.V.; Petersen, W.G.B.; Weber, W.G.; Munro, Z.M. Semiochemicals of the Scarabaeinae. VII: Identification and synthesis of EAD-active constituents of abdominal sex attracting secretion of the male dung beetle. Kheper subaeneus. J. Chem. Ecol. 2002, 28, 2527-2539. [CrossRef] [PubMed]

23. Wang, M.; Carver, J.J.; Phelan, V.V.; Sanchez, L.M.; Garg, N.; Peng, Y.; Nguyen, D.D.; Watrous, J.; Kapono, C.A.; Luzzatto-Knaan, T.; et al. Sharing and community curation of mass spectrometry data with Global Natural Products Social Molecular Networking. Nat. Biotechnol. 2016, 34, 828-837. [CrossRef] [PubMed]

24. Shannon, P.; Markiel, A.; Ozier, O.; Baliga, N.S.; Wang, J.T.; Ramage, D.; Amin, N.; Schwikowski, B.; Ideker, T. Cytoscape: A software environment for integrated models of biomolecular interaction networks. Genome Res. 2003, 13, 2498-2504. [CrossRef] [PubMed]

(C) 2018 by the authors. Licensee MDPI, Basel, Switzerland. This article is an open access article distributed under the terms and conditions of the Creative Commons Attribution (CC BY) license (http:/ / creativecommons.org/licenses/by/4.0/). 